\title{
Land surface phenological response to decadal climate variability across Australia using satellite remote sensing
}

\author{
M. Broich ${ }^{1}{ }^{*}$, A. Huete ${ }^{1}$, M. G. Tulbure ${ }^{2}$, X. Ma ${ }^{1}$, Q. Xin ${ }^{4}$, M. Paget ${ }^{3}$, N. Restrepo-Coupe ${ }^{1}$, K. Davies ${ }^{1}$, R. Devadas ${ }^{1}$, \\ and A. Held ${ }^{3}$ \\ ${ }^{1}$ Plant Functional Biology and Climate Change Cluster, University of Technology, Sydney, NSW 2007, Australia \\ ${ }^{2}$ Centre of Ecosystem Science, School of Biological, Earth and Environmental Sciences, \\ University of New South Wales, Kensington NSW 2052, Australia \\ ${ }^{3}$ CSIRO Marine and Atmospheric Research, Pye Laboratory, Acton, ACT, 2600, Australia \\ ${ }^{4}$ Ministry of Education Key Laboratory for Earth System Modeling, Center for Earth System Science, \\ Tsinghua University, Beijing 100084, China \\ *now at: Centre of Ecosystem Science, School of Biological, Earth and Environmental Sciences, \\ University of New South Wales, Kensington NSW 2052, Australia
}

Correspondence to: M. Broich (mark.broich@unsw.edu)

Received: 31 March 2014 - Published in Biogeosciences Discuss.: 28 May 2014

Revised: 22 August 2014 - Accepted: 22 August 2014 - Published: 29 September 2014

\begin{abstract}
Land surface phenological cycles of vegetation greening and browning are influenced by variability in climatic forcing. Quantitative spatial information on phenological cycles and their variability is important for agricultural applications, wildfire fuel accumulation, land management, land surface modeling, and climate change studies. Most phenology studies have focused on temperature-driven Northern Hemisphere systems, where phenology shows annually recurring patterns. However, precipitation-driven nonannual phenology of arid and semi-arid systems (i.e., drylands) received much less attention, despite the fact that they cover more than $30 \%$ of the global land surface. Here, we focused on Australia, a continent with one of the most variable rainfall climates in the world and vast areas of dryland systems, where a detailed phenological investigation and a characterization of the relationship between phenology and climate variability are missing.

To fill this knowledge gap, we developed an algorithm to characterize phenological cycles, and analyzed geographic and climate-driven variability in phenology from 2000 to 2013, which included extreme drought and wet years. We linked derived phenological metrics to rainfall and the Southern Oscillation Index (SOI). We conducted a continentwide investigation and a more detailed investigation over the
\end{abstract}

Murray-Darling Basin (MDB), the primary agricultural area and largest river catchment of Australia.

Results showed high inter- and intra-annual variability in phenological cycles across Australia. The peak of phenological cycles occurred not only during the austral summer, but also at any time of the year, and their timing varied by more than a month in the interior of the continent. The magnitude of the phenological cycle peak and the integrated greenness were most significantly correlated with monthly SOI within the preceding 12 months. Correlation patterns occurred primarily over northeastern Australia and within the MDB, predominantly over natural land cover and particularly in floodplain and wetland areas. Integrated greenness of the phenological cycles (surrogate of vegetation productivity) showed positive anomalies of more than 2 standard deviations over most of eastern Australia in 2009-2010, which coincided with the transition from the El Niño-induced decadal droughts to flooding caused by La Niña. 


\section{Introduction}

Vegetation phenology refers to the response of vegetation to inter- and intra-annual variations in climate, specifically irradiance, temperature and water (Myneni et al., 1997; White et al., 1997; Zhang et al., 2003). Vegetation phenology is a useful indicator in the study of the response of ecosystems to climate variability (Zhang et al., 2012; Richardson et al., 2013), and an important parameter for land surface, climate and biogeochemical models that quantify the exchange of water, energy and gases between vegetation and the atmosphere (Pitman, 2003; Eklundh and Jönsson, 2010). A variety of applications that require the characterization of vegetation phenology include crop yield quantification, wildfire fuel accumulation, vegetation condition, ecosystem response to climate variability and climate change, and ecosystem resilience (Schwartz, 2003; Liang and Schwartz, 2009; Peñuelas et al., 2009). The phenology of the vegetated land surface (land surface phenology, hereafter phenology) is "the seasonal pattern of variation in vegetated land surfaces observed from remote sensing" (Friedl et al., 2006).

In temperature-limited systems, phenological cycles occur on an annual basis, starting in spring and ending in autumn. Existing algorithms aiming to characterize phenological cycles from remotely sensed spectral vegetation "greenness" indices perform well for ecosystems in temperature-driven mid and high latitudes (Eklundh and Jönsson, 2010; Ganguly et al., 2010). However, in ecosystems where rainfall is limited and highly variable, such as semi-arid and arid systems (i.e., drylands; United Nations, 2011), phenological cycles may be irregular in their length, timing, amplitude and reoccurrence interval, occur at any time of the year, or not occur at all in a given year (Brown and de Beurs, 2008; Ma et al., 2013; Walker et al., 2014; Bradley and Mustard, 2007).

Despite the fact that drylands cover over $30 \%$ of the global land surface and occur on every continent (United Nations, 2011), their rainfall-driven phenology that features non-annual cycles has not been well characterized. Here, we focused on Australia, a continent where drylands cover more than $80 \%$ of the land surface. Recent reports by the Intergovernmental Panel on Climate Change highlighted not only the importance of quantifying vegetation phenology in general (IPCC, 2007, 2013; Schwartz, 2013), but also pointed to a lack of phenological studies for Australia and New Zealand (Keatley et al., 2013; IPCC, 2001, 2007). We developed an algorithm to characterize phenological cycles, and analyzed the phenology of Australia as an example of a rainfall-driven dryland system. Phenology on the landscape-to-continental scale is typically derived using time series of remotely sensed vegetation greenness indices such as the normalized difference vegetation index (NDVI) and the enhanced vegetation index (EVI) (de Beurs and Henebry, 2008). Several studies have used NDVI time series recorded by the Advanced Very High Resolution Radiometer (AVHRR) to investigate long-term phenological trends induced by climate change
(Moulin et al., 1997; Zhang et al., 2012). More recent studies used EVI time series recorded by the MODerate-resolution Imaging Spectroradiometer (MODIS) that has better geometric correction and increased resolution compared to AVHRR (Tan et al., 2011). Compared with NDVI, EVI is less sensitive to residual atmospheric contamination and soil background variations, and has a larger dynamic range of sensitivity to vegetation greenness (Huete et al., 2002). EVI time series measure change in an integrated property commonly referred to as "greenness" has been found to be correlated with subpixel chlorophyll content and leaf area index (Huete et al., 2014).

Parameters describing phenological cycles (hereafter phenological metrics) can be used to quantify the influence of climate change and variability on phenological magnitude (Ma et al., 2013; Brown et al., 2010) and timing (Guan et al., 2014a). Australia has one of the most variable climates in the world, subject to high inter-annual rainfall variability due to the influence of the El Niño-Southern Oscillation (ENSO) (Nicholls, 1991; Nicholls et al., 1997). Previous studies investigated the relationship between vegetation index time series and rainfall globally, and the correlation with soil moisture for Australia (Chen et al., 2014a; Andela et al., 2013). However, studies quantifying the relationship between phenological magnitude and ENSO-related climate variability, as shown for example for Africa (Brown et al., 2010; Philippon et al., 2014), are missing. Here, we analyzed phenological magnitude responses to climate variability through a period of time from 2000 to 2013. This period encompassed the Australian Millennium Drought from 2001 to 2009 (van Dijk et al., 2013) and the 2010-2011 La Niña-associated flooding (Heberger, 2011; Australian Bureau of Meteorology, 2014a), and focused on one of the most affected areas, the MurrayDarling Basin (MDB) in the southeast of Australia (van Dijk et al., 2013; Kirby et al., 2012; Australian Bureau of Meteorology, 2014b).

Particular emphasis was given to the MDB, the catchment of Australia's largest river system, and associated ecologically valuable floodplain and wetland ecosystems and the primary agricultural area of the continent (Connell, 2007).

The objectives of this study were (1) to characterize the inter- and intra-annual variability of phenological cycles of greening and browning, including non-annual cycles across Australia, a continent with vast areas of dryland ecosystems, and (2) to investigate the relationships between the derived phenological magnitude and rainfall, as well as between phenological magnitude and the Southern Oscillation Index (SOI; Trenberth and Caron, 2000), a proxy of ENSO, across the entire continent and in more detail for the MDB. 


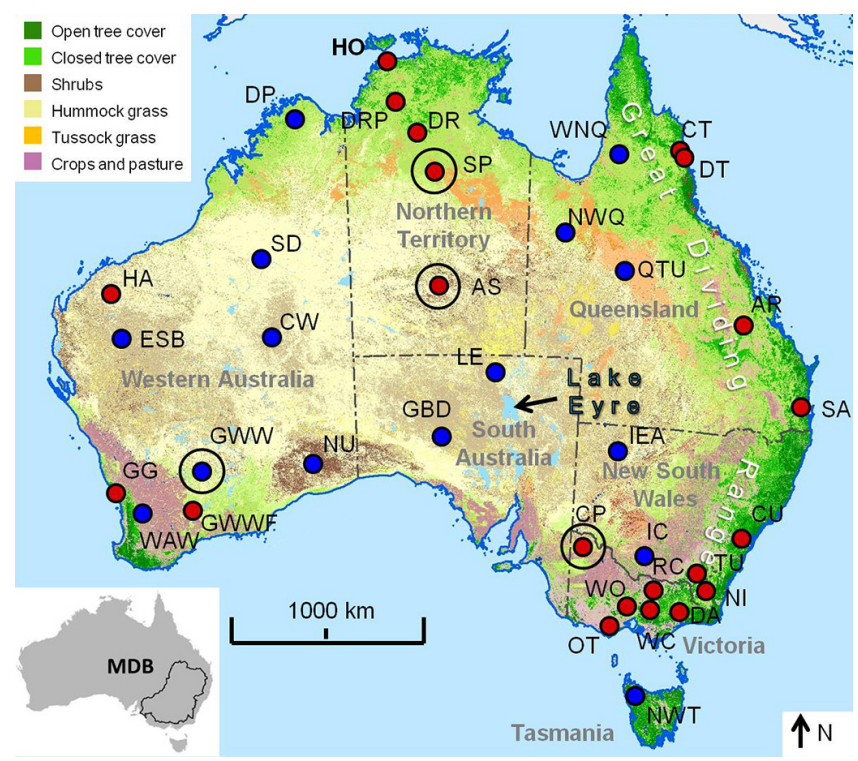

Figure 1. Land cover map of Australia showing closed and open tree cover in dark and light green, respectively. The purple colors that occur predominantly in the southwest and southeast represent crops and pasture. Brown marks shrubs, orange colors mark tussock grass and light brown colors mark hummock grass cover across most of the semi-arid and arid interior (land cover classes were aggregated based on Lymburner et al., 2011). The most prominent topographic feature is the Great Dividing Range that runs along the eastern seaboard. Locations of the 21 OzFlux flux tower sites and 15 additional sites are shown as red and blue circles. We used the EVI time series at the sites for phenological algorithm development and testing (site list provided in Table 1). The phenology for the sites marked by large black circles is presented and discussed in Sect. 2.2.3. The bottom-left panel shows the extent of the MDB.

\section{Methods}

\subsection{Study area and data used}

Australia covers an area of more than 7.6 million $\mathrm{km}^{2}$, and climatic zones range from tropical in the north to temperate in the south (Fig. 1). Average rainfall does not exceed $600 \mathrm{~mm}$ over $80 \%$ of the land area, and is less than $300 \mathrm{~mm}$ over $50 \%$ of the land area (Australian Bureau of Meteorology, 2014c). Northern Australia is dominated by savanna, whereas most of the country is covered by grassland and desert vegetation (Köppen, 1884). Forest occurs at higher elevations in the temperate southwest and southeast, where large areas of the lowlands are used for rain-fed agriculture (Fig. 1; Lymburner et al., 2011). The MDB contains Australia's primary agricultural area, and occupies $14 \%$ of Australia in the southeast of the continent (Fig. 1).

For algorithm development and testing, we used a set of EVI time series at 36 sites distributed across Australia (Fig. 1). These 36 sites represented a range of land cover and climatic zones (Table 1; Lymburner et al., 2011; Australian
Bureau of Meteorology, 2014c) to ensure that the algorithm effectively captures the variability in phenology across the country, and we used them to determine optimized algorithm parameters. The majority (21) of our test sites were flux tower sites from the OzFlux network (2014). We selected 15 additional test sites to represent a wider coverage of climate conditions, vegetation cover and land uses.

As input data for the phenological characterization, we sourced EVI MOD13C2 and MOD13A1 with a temporal resolution of 16 days for the 18 February 2000 to 22 April 2013 time period (NASA Land Processes Distributed Active Archive Center, 2014).

We used the $5.6 \mathrm{~km}$ product (MOD13C2) to characterize the biogeographic patterns of vegetation phenology across the entire Australian continent, and the $500 \mathrm{~m}$ product (MOD13A1) to investigate the phenological patterns in more detail across the MDB. We chose the 16-day versions of the products, as they attenuate the noise present in higher temporal resolution versions (Solano et al., 2012).

To analyze the responses of phenological metrics to rainfall variability, we used monthly data from the Tropical Rainfall Monitoring Mission Project (TRMM_3B43.v7 product; Goddard Space Flight Center, 2014) with a $0.25^{\circ} \times 0.25^{\circ}$ spatial resolution for 1999-2012. Instead of using gridded rainfall data interpolated from widely spaced weather stations across large areas of the interior, we opted for remotely sensed rainfall measured by TRMM, which is systematic across space and time.

To analyze the responses of phenological metrics to ENSO, we used monthly data of the Southern Oscillation Index (SOI) obtained from the Australian Bureau of Meteorology (2014d). SOI represents the standardized difference in air pressures between Darwin and Tahiti, and serves as a proxy of convection in the western Pacific caused by ENSO sea surface temperature anomalies (Trenberth and Caron, 2000).

Across the MDB, we used the Dynamic Land Cover data set provided by Geoscience Australia (Lymburner et al., 2011) to investigate the differences between the phenological responses to SOI and rainfall over natural and managed land cover types. We derived the natural land cover class by grouping land cover dominated by trees, shrubs and grasses. The managed land cover classes encompassed rainfed and irrigated agriculture and pasture. Almost a third of the basin's area is managed for cropping and pasture (Lymburner et al., 2011). We also analyzed the phenological response over the ecologically valuable floodplain and wetland areas of MDB (Kingsford et al., 2004), and evaluated the floodplain's response to SOI as a proxy of ENSO-related drought and flooding. 
Table 1. Names, locations, land cover class (Lymburner et al., 2011) and average annual rainfall amounts (Australian Bureau of Meteorology, 2014c) for the 36 sites shown in Fig. 1

\begin{tabular}{|c|c|c|c|c|c|c|}
\hline Site name & $\begin{array}{l}\text { OzFlux } \\
\text { site }\end{array}$ & $\begin{array}{l}\text { Site code } \\
\text { Fig. } 1\end{array}$ & $\begin{array}{l}\text { Lat. } \\
\left({ }^{\circ} \mathrm{S}\right)\end{array}$ & $\begin{array}{l}\text { Long. } \\
\left({ }^{\circ} \mathrm{E}\right)\end{array}$ & $\begin{array}{l}\text { Land cover } \\
\text { classes }\end{array}$ & $\begin{array}{l}\text { Average annual } \\
\text { rainfall }(\mathrm{mm})\end{array}$ \\
\hline Nullaboure & & NU & -30.275 & 127.175 & $\begin{array}{l}\text { Woody } \\
\text { shrubs, } \\
\text { scattered }\end{array}$ & 200 \\
\hline $\begin{array}{l}\text { Great } \\
\text { Blight } \\
\text { Desert }\end{array}$ & & GBD & -29.125 & 133.075 & $\begin{array}{l}\text { Woody } \\
\text { shrubs, } \\
\text { sparse }\end{array}$ & 200 \\
\hline Lake Eyre & & LE & -27.425 & 137.225 & $\begin{array}{l}\text { Woody } \\
\text { shrubs, } \\
\text { sparse }\end{array}$ & 200 \\
\hline $\begin{array}{l}\text { Great } \\
\text { Western } \\
\text { Woodlands }\end{array}$ & & GWW & -30.225 & 120.625 & $\begin{array}{l}\text { Woody } \\
\text { trees, } \\
\text { scattered }\end{array}$ & 300 \\
\hline $\begin{array}{l}\text { East of } \\
\text { Shark Bay }\end{array}$ & & ESB & -24.475 & 116.325 & $\begin{array}{l}\text { Woody } \\
\text { shrubs, } \\
\text { sparse }\end{array}$ & 300 \\
\hline $\begin{array}{l}\text { Central } \\
\text { Western } \\
\text { Australia }\end{array}$ & & $\mathrm{CW}$ & -24.125 & 124.175 & $\begin{array}{l}\text { Woody } \\
\text { shrubs, } \\
\text { sparse }\end{array}$ & 300 \\
\hline $\begin{array}{l}\text { Interior } \\
\text { south- } \\
\text { eastern } \\
\text { Australia }\end{array}$ & & IEA & -29.425 & 144.225 & $\begin{array}{l}\text { Woody } \\
\text { shrubs, } \\
\text { sparse } \\
\text { chenopods }\end{array}$ & 300 \\
\hline Calperum & $\mathrm{X}$ & $\mathrm{CP}$ & -34.025 & 140.375 & $\begin{array}{l}\text { Woody } \\
\text { trees, } \\
\text { scattered }\end{array}$ & 300 \\
\hline $\begin{array}{l}\text { Western } \\
\text { Australian } \\
\text { wheat belt }\end{array}$ & & WAW & -32.125 & 117.425 & $\begin{array}{l}\text { Herbaceous } \\
\text { graminoids, } \\
\text { rain-fed }\end{array}$ & 400 \\
\hline $\begin{array}{l}\text { Irrigated } \\
\text { cropping }\end{array}$ & & IC & -35.275 & 145.275 & $\begin{array}{l}\text { Herbaceous } \\
\text { graminoids, } \\
\text { rain-fed }\end{array}$ & 400 \\
\hline $\begin{array}{l}\text { Alice } \\
\text { Springs }\end{array}$ & $\mathrm{X}$ & AS & -22.275 & 133.225 & $\begin{array}{l}\text { Herbaceous } \\
\text { graminoids, } \\
\text { sparse } \\
\text { hummock } \\
\text { grasses }\end{array}$ & 400 \\
\hline $\begin{array}{l}\text { Simpson } \\
\text { Desert }\end{array}$ & & SD & -20.475 & 124.025 & $\begin{array}{l}\text { Herbaceous } \\
\text { graminoids, } \\
\text { sparse } \\
\text { hummock } \\
\text { grasses }\end{array}$ & 400 \\
\hline Hamersley & $\mathrm{X}$ & HA & -22.275 & 115.725 & $\begin{array}{l}\text { Woody } \\
\text { shrubs, } \\
\text { sparse }\end{array}$ & 400 \\
\hline $\begin{array}{l}\text { Great } \\
\text { Western } \\
\text { Woodlands } \\
\text { flux }\end{array}$ & $\mathrm{X}$ & GWWF & -31.925 & 120.075 & $\begin{array}{l}\text { Herbaceous } \\
\text { graminoids, } \\
\text { sparse } \\
\text { hummock } \\
\text { grasses }\end{array}$ & 400 \\
\hline $\begin{array}{l}\text { Queensland } \\
\text { tussock }\end{array}$ & & QTU & -21.225 & 143.075 & $\begin{array}{l}\text { Herbaceous } \\
\text { graminoids, } \\
\text { sparse } \\
\text { hummock } \\
\text { grasses }\end{array}$ & 500 \\
\hline
\end{tabular}


Table 1. Continued.

\begin{tabular}{|c|c|c|c|c|c|c|}
\hline Site name & $\begin{array}{l}\text { OzFlux } \\
\text { site }\end{array}$ & $\begin{array}{l}\text { Site code } \\
\text { Fig. } 1\end{array}$ & $\begin{array}{l}\text { Lat. } \\
\left({ }^{\circ} \mathrm{S}\right)\end{array}$ & $\begin{array}{l}\text { Long. } \\
\left({ }^{\circ} \mathrm{E}\right)\end{array}$ & $\begin{array}{l}\text { Land cover } \\
\text { classes }\end{array}$ & $\begin{array}{l}\text { Average annual } \\
\text { rainfall }(\mathrm{mm})\end{array}$ \\
\hline $\begin{array}{l}\text { Northwestern } \\
\text { Queensland }\end{array}$ & & NWQ & -19.525 & 140.025 & $\begin{array}{l}\text { Woody } \\
\text { trees, } \\
\text { scattered }\end{array}$ & 600 \\
\hline Sturt Plain & $\mathrm{X}$ & SP & -17.175 & 133.375 & $\begin{array}{l}\text { Woody } \\
\text { trees, } \\
\text { sparse }\end{array}$ & 600 \\
\hline Riggs Creek & $\mathrm{x}$ & $\mathrm{RC}$ & -36.625 & 145.575 & $\begin{array}{l}\text { Herbaceous } \\
\text { graminoids, } \\
\text { rain-fed } \\
\text { pasture }\end{array}$ & 800 \\
\hline Arcturus & $\mathrm{X}$ & $\mathrm{AR}$ & -23.875 & 149.275 & $\begin{array}{l}\text { Woody } \\
\text { trees, open }\end{array}$ & 800 \\
\hline Gingin & $\mathrm{X}$ & GG & -31.375 & 115.725 & $\begin{array}{l}\text { Woody } \\
\text { trees, } \\
\text { sparse }\end{array}$ & 800 \\
\hline Otway & $\mathrm{X}$ & OT & -38.525 & 142.825 & $\begin{array}{l}\text { Herbaceous } \\
\text { graminoids, } \\
\text { rain-fed } \\
\text { pasture }\end{array}$ & 1000 \\
\hline Wombat & $\mathrm{x}$ & Wo & -37.425 & 144.075 & $\begin{array}{l}\text { Woody } \\
\text { trees, } \\
\text { closed }\end{array}$ & 1000 \\
\hline $\begin{array}{l}\text { Cumberland } \\
\text { Plain }\end{array}$ & $\mathrm{x}$ & $\mathrm{CU}$ & -33.725 & 150.725 & $\begin{array}{l}\text { Woody } \\
\text { trees, } \\
\text { sparse }\end{array}$ & 1000 \\
\hline Dry River & $\mathrm{X}$ & DR & -15.275 & 132.375 & $\begin{array}{l}\text { Woody } \\
\text { trees, } \\
\text { sparse }\end{array}$ & 1000 \\
\hline $\begin{array}{l}\text { Wallaby } \\
\text { Creek }\end{array}$ & $\mathrm{X}$ & WC & -37.425 & 145.175 & $\begin{array}{l}\text { Woody } \\
\text { trees, } \\
\text { closed }\end{array}$ & 1200 \\
\hline $\begin{array}{l}\text { Daly River } \\
\text { pasture }\end{array}$ & $\mathrm{x}$ & DRP & -14.075 & 131.375 & $\begin{array}{l}\text { Woody } \\
\text { trees, open }\end{array}$ & 1200 \\
\hline $\begin{array}{l}\text { West of } \\
\text { northern } \\
\text { Queensland }\end{array}$ & & WNQ & -16.275 & 142.475 & $\begin{array}{l}\text { Woody } \\
\text { trees, } \\
\text { sparse }\end{array}$ & 1200 \\
\hline Nimmo & $\mathrm{x}$ & NI & -36.225 & 148.575 & $\begin{array}{l}\text { Woody } \\
\text { trees, } \\
\text { closed }\end{array}$ & 1600 \\
\hline Samford & $\mathrm{X}$ & SA & -27.425 & 152.825 & $\begin{array}{l}\text { Woody } \\
\text { trees, } \\
\text { closed }\end{array}$ & 1600 \\
\hline Tumbarumba & $\mathrm{x}$ & TU & -35.675 & 148.175 & $\begin{array}{l}\text { Woody } \\
\text { trees, open }\end{array}$ & 1600 \\
\hline $\begin{array}{l}\text { Howard } \\
\text { Springs }\end{array}$ & $\mathrm{X}$ & $\mathrm{HO}$ & -12.475 & 131.175 & $\begin{array}{l}\text { Woody } \\
\text { trees, open }\end{array}$ & 1600 \\
\hline $\begin{array}{l}\text { Dampier } \\
\text { peninsula }\end{array}$ & & DP & -15.125 & 125.725 & $\begin{array}{l}\text { Woody } \\
\text { trees, } \\
\text { sparse }\end{array}$ & 1600 \\
\hline Dargo & $\mathrm{X}$ & DA & -37.125 & 147.175 & $\begin{array}{l}\text { Herbaceous } \\
\text { graminoid } \\
\text { rain-fed } \\
\text { pasture }\end{array}$ & 2000 \\
\hline $\begin{array}{l}\text { Northwestern } \\
\text { Tasmania }\end{array}$ & & NWT & -41.225 & 145.175 & $\begin{array}{l}\text { Woody } \\
\text { trees, } \\
\text { closed }\end{array}$ & 2000 \\
\hline $\begin{array}{l}\text { Cape Tribula- } \\
\text { tion }\end{array}$ & $\mathrm{x}$ & $\mathrm{CT}$ & -16.125 & 145.375 & $\begin{array}{l}\text { Woody } \\
\text { trees, } \\
\text { closed }\end{array}$ & 8000 \\
\hline Daintree & $\mathrm{X}$ & DT & -16.225 & 145.425 & $\begin{array}{l}\text { Woody } \\
\text { trees, } \\
\text { closed }\end{array}$ & 8000 \\
\hline
\end{tabular}




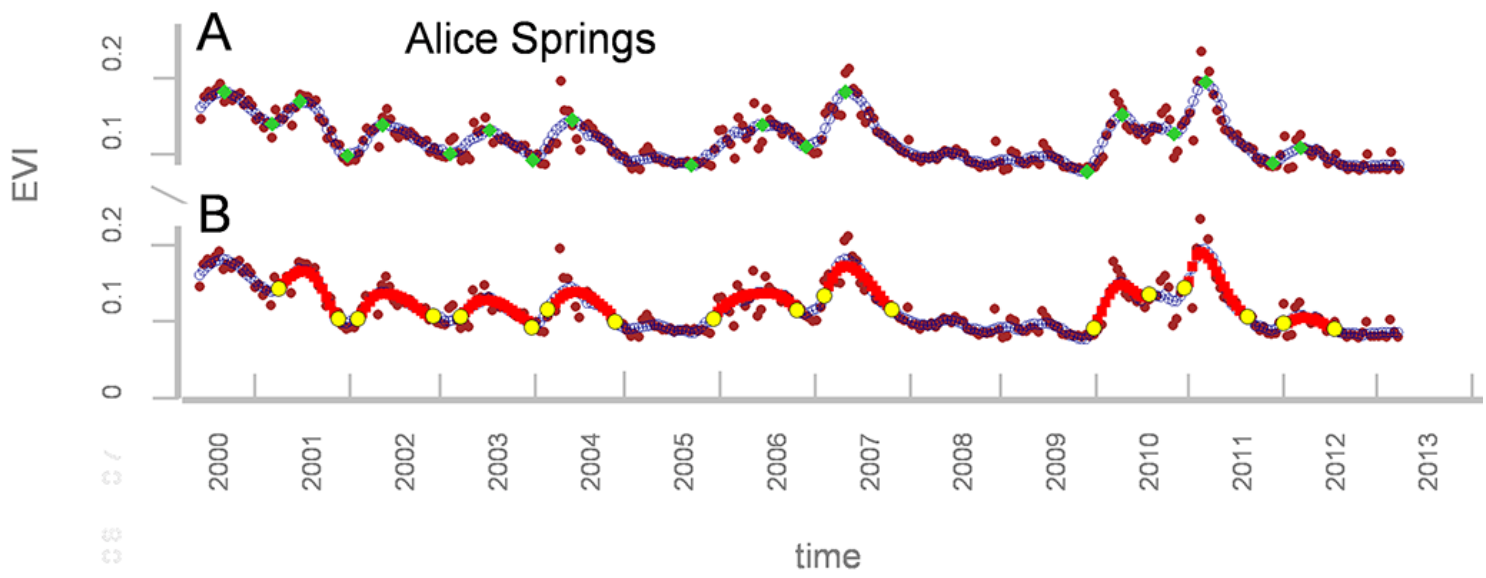

Figure 2. Algorithm steps applied to the 14-year MODIS EVI time series (MOD13C2 single $5.6 \mathrm{~km}$ pixel) for the Alice Springs flux site, representing semi-arid mulga (Acacia) woodland of the center of Australia. (a) EVI time series after screening out low-quality observations (brown circles), EVI time series after gap filling and smoothing (blue circles), and flagged minimum and peak-of-cycle points (green diamonds). (b) Curves fitted as seven-parameter double logistic functions (red squares) characterizing the phenological cycles, and identifying start- and end-of-cycle points (yellow circles) delineating the cycles. The timing, length, amplitude, and magnitudes of the phenological cycles at the site vary inter-annually.

\subsection{Phenology metrics and algorithm}

\subsubsection{Phenology metrics}

To account for non-annual vegetation dynamics, we defined a phenological cycle not as an annually or seasonally recurring event, but more broadly, as a cycle of EVI-measured greening and browning that may occur more than once per year or may skip a year entirely and not occur for one or more years.

We modeled phenological cycle curves and key properties of each phenological cycle in the form of curve metrics. The phenological metrics modeled the timing and magnitude of key transitional points on the cycle's curve, and included the timing and magnitude of the minimum points before and after a phenological cycle, the peak point of the cycle and the start and end point of the cycle. In addition, we also calculated the integrated area between the start and end points of a cycle as a surrogate of vegetation productivity during a cycle (Zhang et al., 2013). By tracking the phenological cycle metrics over time, we characterized the intra- and inter-annual variability of the phenological cycle, and thereby vegetation growth patterns.

\subsubsection{Data pre-processing}

We used the quality assurance flags in the MOD13 products to discard observations with insufficient quality, which included any observation with either VI usefulness greater than code "10", snow cover, high aerosol or climatology aerosol quantity, mixed or high clouds present, or water in the Land/Water Flag. For each pixel, we first used cubic spline interpolation (Dougherty et al., 1989) to temporally gap-fill the data points discarded in the previous filtering step. Next, we smoothed the time series for each pixel using a SavitzkyGolay smoothing filter (Savitzky and Golay, 1964) with a window width of 15 time steps. This step effectively reduced the remaining noises in the time series that would otherwise impact the identification of minimum and maximum points and the subsequent fitting of a mathematical curve that we conducted to characterize the phenological cycles in a consistent way.

\subsubsection{Curve fitting and phenological metric derivation}

We identified local minimum and maximum points of the per-pixel time series using a moving window of nine time steps and a $>0.01 \mathrm{EVI}$ amplitude threshold to identify cycles of greening and browning. We used the identified minimum points to define the temporal extent of phenological cycles in the entire time series. We then fitted the sevenparameter double logistic model for each identified interval. We did not expect one or multiple phenological cycles in fixed intervals of the year. We thus allowed cycles to be characterized at any time to better represent the highly variable rainfall-driven phenological patterns across Australia's vast drylands and dual cycles in cropping and pasture zones. We fitted seven-parameter double logistic curves to each cycle in the per-pixel time series, defined as

$$
\operatorname{EVI}(t)=V_{\text {min }_{\mathrm{a}}}-\frac{V_{\max }-V_{\text {min }_{\mathrm{a}}}}{1+\exp \left(\frac{T_{\text {mida }_{\mathrm{a}}-t}}{S_{\mathrm{a}}}\right)}+\frac{V_{\text {max }}-V_{\text {min }_{\mathrm{b}}}}{1+\exp \left(\frac{T_{\text {mid }_{\mathrm{b}}}-t}{S_{\mathrm{b}}}\right)},
$$

where $V_{\min _{\mathrm{a}}}$ and $V_{\min _{\mathrm{b}}}$ are equal to the first and second minimum EVI, respectively. $V_{\max }$ is the high asymptote in the double logistic model, and $T_{\text {mida }_{a}}$ is the time when EVI reached half of $V_{\max }-V_{\min _{\mathrm{a}}} . T_{\text {mid }_{\mathrm{b}}}$ is the time when EVI 


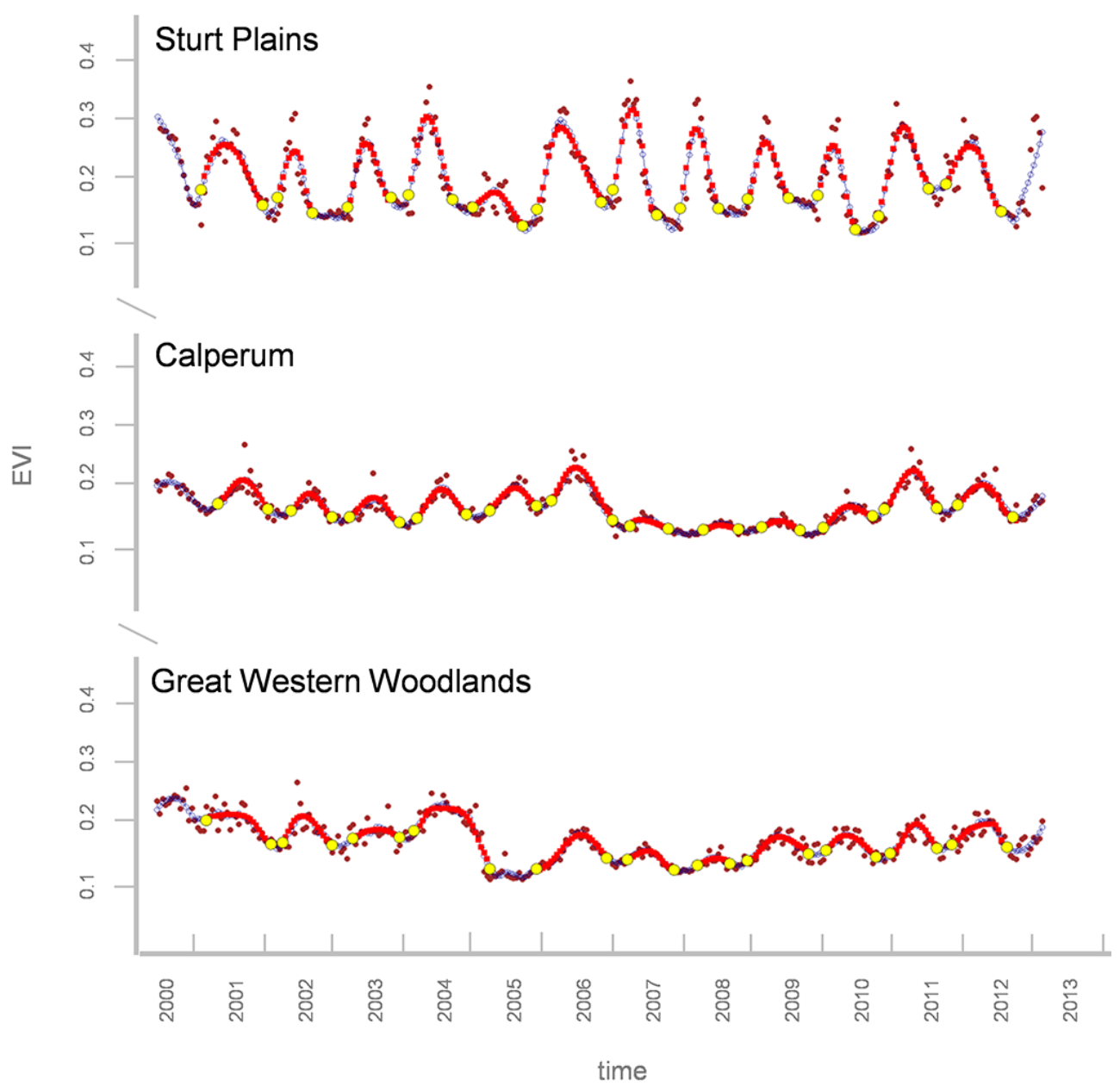

Figure 3. Examples of temporal variability of the characterized phenological cycles for the Sturt Plains, Calperum, and Great Western Woodlands sites (refer to Fig. 1 and Table 1 for the sites' locations and descriptions, respectively), based on 14 years of MODIS EVI data after screening out low-quality observations (brown circles), EVI time series after gap filling and smoothing (blue circles), fitting seven-parameter double logistic functions (red squares) and identifying the start- and end-of-cycle points (yellow circles) delineating the characterized phenological cycles.

reached half of $V_{\max }-V_{\min _{\mathrm{b}}} . S_{\mathrm{a}}$ and $S_{\mathrm{b}}$ are the scale parameters on the increasing and decreasing sides of the curve, respectively. We identified the start and end points of each cycle as the points where the EVI reached $20 \%$ of the amplitude, between the first minimum and the peak, and the peak and the second minimum, respectively, as also used in other studies (Eklundh and Jönsson, 2010; Tan et al., 2011; Jones et al., 2011; Delbart et al., 2005).

An example of the algorithm processing steps is shown for the Alice Springs flux tower site (Fig. 2). The site represents Acacia woodlands in the arid interior of Australia. The site serves as an example showing how our algorithm derives phenological metrics to characterize the high temporal variability in phenological cycles for the interior of Australia.

We provide further examples of how the algorithm characterized the phenological cycles over different land cover types in different rainfall zones in Fig. 3. The sites' locations and descriptions are provided in Fig. 1 and Table 1, respectively.

\subsection{Analysis of spatial-temporal patterns of phenology across Australia}

After deriving phenological cycles and their metrics from per-pixel greenness time series, we analyzed the metrics across Australia at two levels of temporal aggregation: (1) in the form of summary statistics (mean and standard deviation) across greenness time series to quantify overall phenological variability over the 14-year time series; and (2) in the form of inter-cyclic variability as the difference between a metric of one cycle and the following cycle over the 14-year time series.

For a given site, we calculated for example the mean peak magnitude and the peak magnitude's standard deviation. An example of inter-cycle variability of metrics is our analysis 
of peak timing for all peaks across the time series. We also analyzed the deviation of an individual phenological cycle integral relative to the expected variability. For this purpose, we calculated the standardized anomaly of each cycle's integral as the difference of the cycle's integral from the mean integral divided by the standard deviation of the integrals.

\subsection{Analysis of spatial-temporal patterns of Australian phenology in response to rainfall and SOI variability}

We further analyzed the statistical relationship between phenological cycle peak magnitude and cycle-integrated greenness with TRMM rainfall and SOI (four combinations of correlation analyses) across Australia and in more detail for the MDB. The cycle peak magnitude represents maximum greenness, while the cycle-integrated greenness serves as a proxy of ecosystem productivity (Zhang et al., 2013). We used non-parametric Spearman rank correlation tests (Lehmann and D'Abrera, 1975), hereafter Spearman rho, to determine the strength and significance of monotonic relationships between rainfall and each of the two phenology metrics, as well as SOI and the two phenology metrics. We evaluated relationships between rainfall and SOI as the explanatory variables binned over different intervals and with different lead times to the phenological cycle integral and peak magnitude, which were used as the response variables. We binned rainfall accumulation for intervals of 1 to 12 months and average SOI values for periods of 1 to 12 months up to 12 months prior to the phenological cycle peak.

The underlying assumption for investigating Spearman rho correlations between phenology and rainfall or SOI was that a significant and strong monotonic relationship between a phenological metric and preceding rainfall or SOI suggested that the phenology metric (peak magnitude and integrated greenness) is likely driven by the respective climate variable.

Aiming to identify correlation patterns and how these patterns change as a function of binning interval (1-12 months) and lead times (up to 12 months), we extracted for each pixel and binning interval the most significant test result. For each potential driver and binning interval, we analyzed the lead time, correlation and significance value. We illustrated the results only for areas that were significant ( $p$ value less than 0.05 ) and had a rho value of greater than 0.6.

Using the above methodology, we conducted a continentwide analysis and a higher-resolution analysis investigating the relationship of SOI with phenology metrics for the MDB in southeastern Australia. Within the MDB, we further investigated the relationship between SOI and phenology (differences in correlation patterns) over natural and managed land cover types, as well as the catchment's floodplain and wetlands.
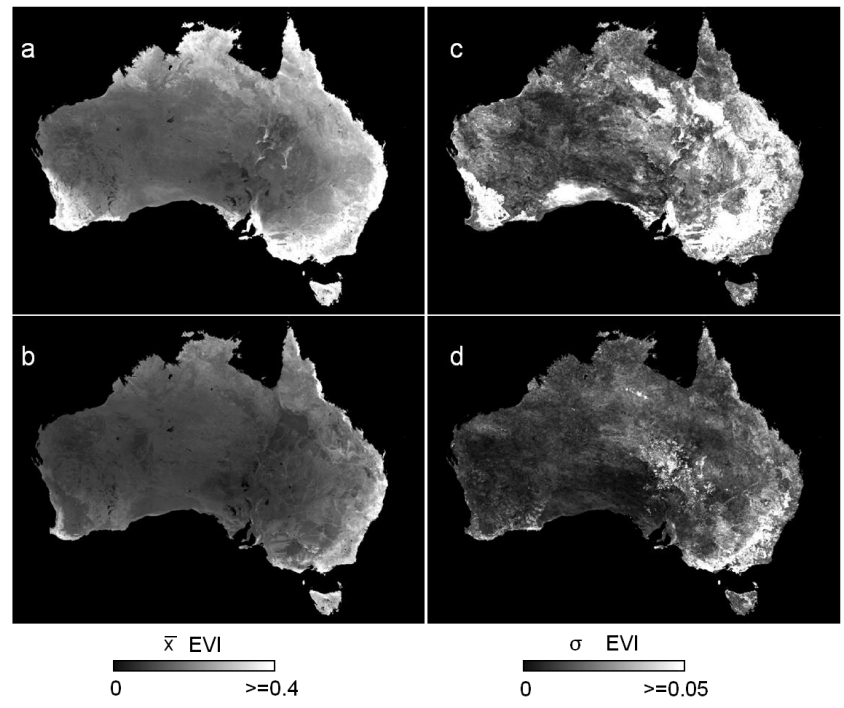

Figure 4. Mean of peak magnitude (a), mean of minimum magnitude (b), standard deviation of peak magnitude (c) and standard deviation of minimum magnitude (d). A map of the dominant land cover type is provided in Fig. 1.

\section{Results}

\subsection{Mean and variability of peak and minimum magnitude as well as start and end of cycle timing across 14 years}

We evaluated the mean and variability of the peak and minimum magnitude across the 14-year time series to investigate the inter-annual variations in vegetation phenology. The highest mean peak magnitude occurred in a narrow area covered predominantly by evergreen humid tropical forest along the northeastern coast (areas with high EVI in Fig. 4a and b). The same area also had the highest mean minimum magnitude values, indicating that greenness was persistently high (light colored areas in Fig. 4b). Other areas with high levels of persistent greenness (areas with high mean peak magnitude and high mean minimum magnitude) included temperate grasslands in coastal locations of southeastern Australia, temperate broadleaf forest in the southeast and southwest of the continent, and across most of Tasmania (light colored areas in Fig. 4a and b). The largest mean seasonal amplitude (peak minus minimum magnitude) occurred in areas used for crop cultivation and grazing in the southwest and southeast. Areas of low mean peak amplitude were found across large parts of the interior (darker toned areas in both Fig. 4a and b), with the exception of the desert river beds.

The highest level of variability in peak magnitude occurred over cropped areas in the southeast and southwest of Australia (light colored areas in Fig. 4c). High variability of peak magnitude over natural vegetation cover was observed for example for regions predominantly covered with tropical 

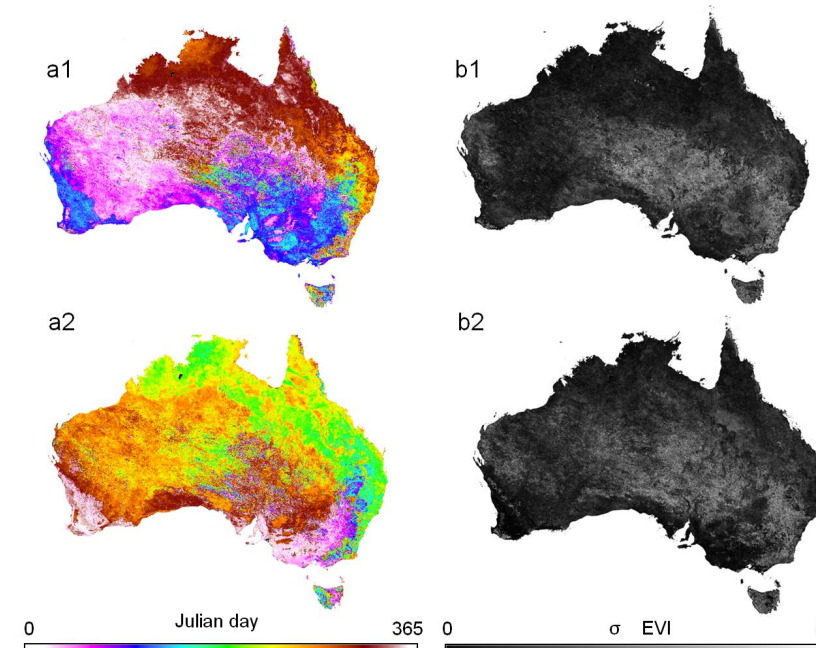

b2

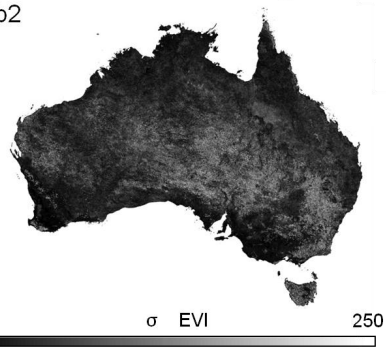

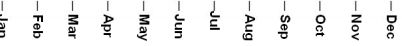

Figure 5. Mean Julian day of the start of the phenological cycles (a1), standard deviation of the start of the phenological cycles in number of days (b1), mean Julian day of the end of the phenological cycles (a2) and standard deviation of the end of the phenological cycles in number of days (b2) across the 14-year time series.

tussock grasses in the inland north and northeast, as well as areas with predominant chenopod woody shrub cover along the Great Australian Bight along the southern coast of Australia (light colored areas in Fig. 4c). High variability in minimum magnitude occurred at higher elevations of the southern Great Dividing Range in the southeast of Australia (light colored areas in Fig. 4d) and around the center of the arid Lake Eyre, which is the lowest point of the continent.

We also evaluated the mean and variability of the start and end of cycle timing across the 14-year time series. Across western and southeastern Australia, the mean start of cycles occurred during the first half of the year, and the mean end of the cycle occurred in the second half of the year (Fig. 5a1). Across northern and eastern Australia, the mean start of cycles occurred during the second half of the year, and the mean end of cycle occurred in the first half of the following year (Fig. 5a2). The variability in the start and end of the cycle was highest across interior Australia, with the area of high variability being higher for the end of cycle timing (Fig. 5b1 and 2).

\subsection{Inter-cycle variability in peak timing}

The timing of the first cycles' peak within each year showed large variation from one year to another across most of Australia (Fig. 6). Variations in peak timing were observed over most of interior Australia. Peak timing was later than average in 2001, 2004 and 2005 (Fig. 6), but earlier in 20102012 over interior Australia (Fig. 6). The peak timing in the wet tropical savannas of the Northern Territory and for most

of the southwestern wheat belt was relatively stable (Fig. 6). The center of the continent showed an earlier-than-average peak in 2002 and 2009.

Over interior Australia, peak timing varied by over a month from one year to another. Areas for which no peak was observed in a given year (shown in gray in Fig. 6) occurred primarily in the drylands of the continent's interior, where phenological cycles may not follow an annually recurring pattern. For example, areas with no peak over interior Australia in Fig. 6 for 2005 and 2008 can also be traced in Fig. 2, where the phenology of the Alice Springs site did not show a peak in those years.

\subsection{Variability of cycle-integrated greenness}

Greenness integrated between the start and end of a phenological cycle can provide a first approximation of vegetation productivity (Ponce Campos et al., 2013; Zhang et al., 2013). Standardized anomalies of integrated greenness highlight the deviation of an individual value from the mean, relative to the expected level of variability (the standard deviation). Standardized anomalies of integrated greenness were highly variable across time (Fig. 7). Negative standardized anomalies of integrated greenness (red tones in Fig. 7) occurred across the continent in most areas in 2002, and in vast areas of the continent in 2008 and 2009. Large areas of negative anomalies also occurred in 2001, 2003 and from 2004 to 2007. Large areas of positive standardized anomalies (green tones in Fig. 8), with an increased greening of 1-2 standard deviations, occurred in 2010, a year of particularly high rainfall.

When relating the cycles' standardized anomalies of integrated greenness to the phenology at the Alice Springs tower site, the widespread negative standardized anomaly over interior Australia in 2008 (Fig. 7) was not represented on the site's curve (Fig. 2), where no cycle started or ended in 2008 and 2009. Conversely, the positive standardized anomalies of cycles that started in 2010 and 2011 over large areas of eastern and interior Australia can also be seen on the $\mathrm{Al}$ ice Springs curve in the form of larger-than-average integrals (Fig. 2).

\subsection{Analysis of spatial-temporal patterns of Australian phenology relative to rainfall and SOI variability}

We conducted a correlation analysis relating two climate drivers (SOI and rainfall) and two phenological metrics (first peak magnitude and cycle integral of each year), respectively (four combinations). Each of the four analyses included climate drivers binned over periods between 1 and 12 months within the 12-month period leading up to the phenological peak. We found that areas with significant correlations between SOI and phenology or rainfall and phenology were most widespread for a binning interval of 1 month. Areas with significant correlations shrank as we increased the binning interval of SOI or rainfall from 1 to 12 months. 

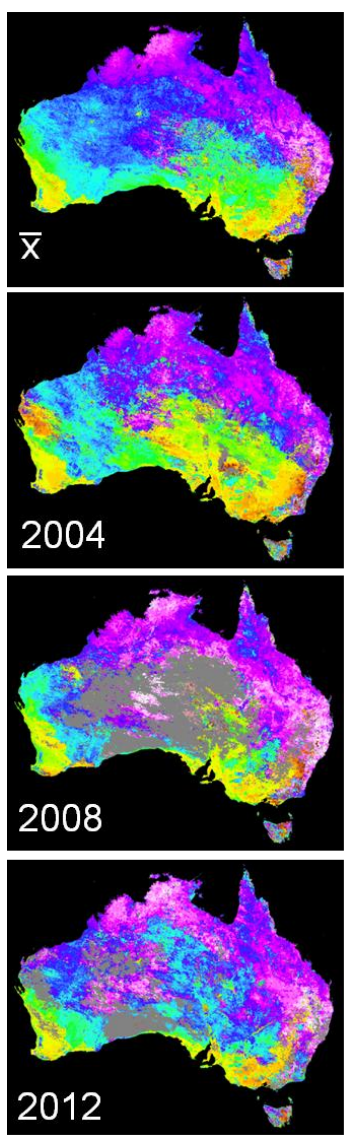
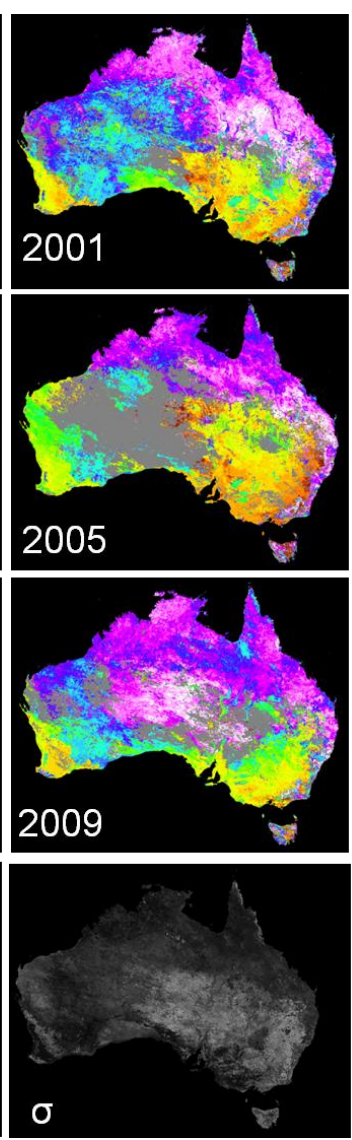
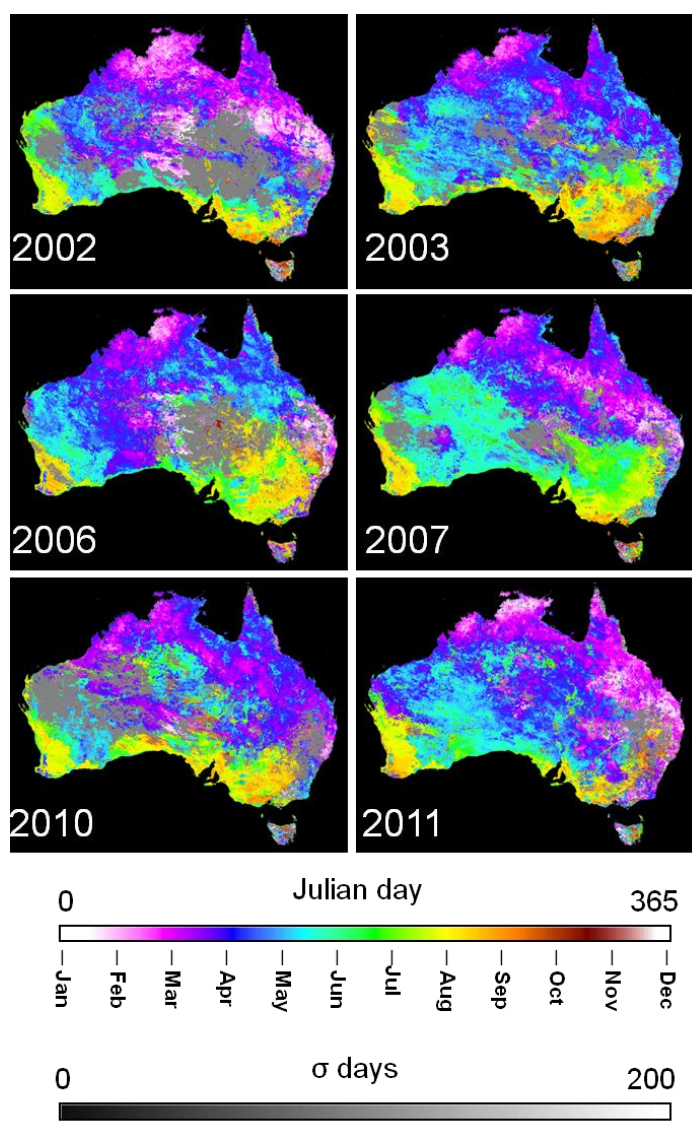

Figure 6. Inter-annual variation in the peak timing. The Julian day of the phenological cycles' peak is displayed in the calendar year when the peak occurred. The mean $(\bar{x})$ and standard deviation $(\sigma)$ of the cycle peak timing are provided for reference. The scale is cyclic. Areas where no peak was observed during a given calendar year are shown in gray.

The spatial pattern of significant correlations (areas significantly correlated, correlation strength, and lead times) was generally similar for all four combinations of variables. However, the patterns of significant correlation between peak magnitude and climate variables covered a larger area compared to patterns of significant correlation between cycle integral and climate variables. The patterns of significant SOI-driven correlation with phenology covered a larger and more concentrated area compared to the rainfall-driven correlation patterns. Given the above similarities and the largest extent of significant correlation patterns at a singlemonth binning interval, we limit the presentation of results to the most significant monthly SOI and - cycle peak magnitude and the most significant monthly rainfall - cycle peak magnitude correlation.

The most significant correlations between monthly SOI and cycle peak magnitude and monthly rainfall and cycle peak magnitude were most widespread in northeastern Australia (Fig. 8c). Lead times between the most significantly correlated driver month and the phenological cycle peak were 1-6 months for northeastern Australia and 7-12 months for the eastern Australian interior, representing an increase in lead time along a gradient of decreasing rainfall (Fig. 8a and b). These correlation patterns extended into the Australian interior along desert river drainage lines such as the Cooper Creek. The floodplain of the middle reach of the Cooper Creek can be clearly distinguished in the correlation pattern, indicating a strong response of the floodplain vegetation to, for example, SOI variability (Fig. 9). Additional correlation patterns with a shorter lag time behind SOI (1-3 months) were observed near the western coast of Australia, with longer lag times of 5-8 months behind rainfall (Fig. 8a).

In the MDB, correlation patterns between monthly SOI and cycle peak magnitude occurred primarily over natural vegetation cover, as opposed to areas used for agriculture or pasture (managed land cover). The percentage of all significant relationships over natural land cover was $83.6 \%$, as opposed to $15.9 \%$, the percentage of all significant relationships over managed land cover (Table 2). These percentages were disproportional to areal percentages of natural and managed land cover within the MDB $(71.8$ and $28.2 \%$, respectively). The highest percentage of significantly correlated areas within each land cover class and the highest mean rho values were found in areas dominated by shrubs, trees and 

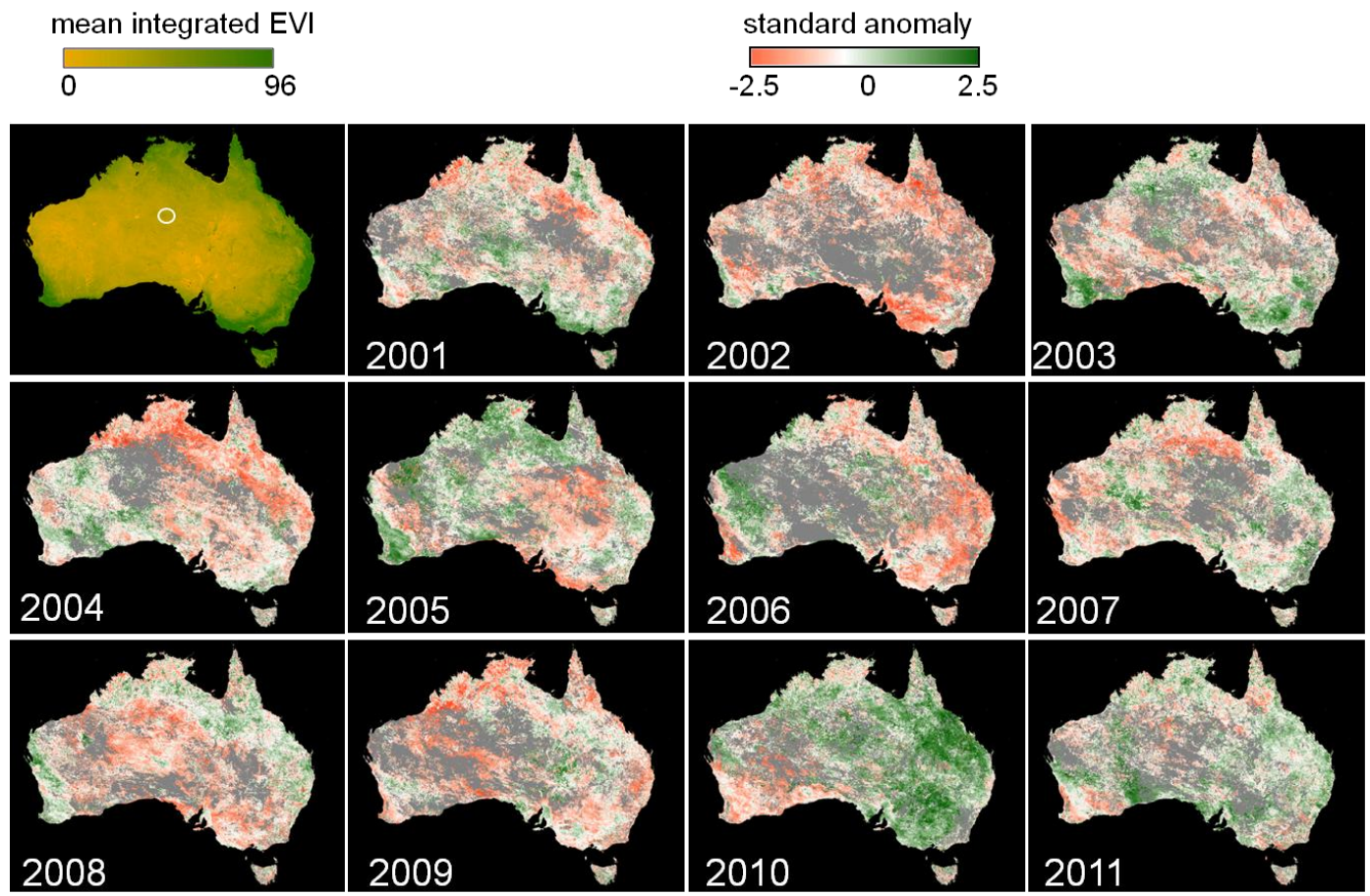

Figure 7. Mean of the cycles' integral greenness across the time series (top-left panel in day units) and standardized anomaly of each cycle's integrated greenness. The standardized anomalies of the cycles are shown in the year when the cycle started. For example, for a site with six phenological cycles across the time series that started in 2001, 2002, 2003, 2005, 2008 and 2010, the cycles' standard deviations are shown in 2001, 2002, 2003, 2005, 2008 and 2010. All other years are shown in gray, as no phenological cycle start was detected for those years. The white circle in the top-left panel marks the OzFlux site shown in Fig. 2.

Table 2. Percentage distribution of the most significant correlation relationships between monthly SOI and phenological peak magnitude per land cover class across the MDB. Shown are percentages of the MDB occupied by different land covers, the percentage of basin-wide significantly correlated areas per land cover, the percentage of significantly correlated land cover classes and the average rho value per land cover.

\begin{tabular}{lcccc}
\hline $\begin{array}{l}\text { Aggregated land } \\
\text { cover classes (LCCs) }\end{array}$ & $\begin{array}{c}\text { \% of } \\
\text { basin covered } \\
\text { by each LCC }\end{array}$ & $\begin{array}{c}\text { \% of the areas of significant } \\
\text { correlations between monthly SOI and } \\
\text { peak magnitude within each LCC }\end{array}$ & $\begin{array}{c}\text { \% of each LCC where a significant } \\
\text { correlation between monthly SOI } \\
\text { and peak magnitude occurred }\end{array}$ & $\begin{array}{c}\text { Average rho of significant } \\
\text { correlations within LCC }\end{array}$ \\
\hline Trees & 43.0 & 48.7 & 5.2 & 0.71 \\
Shrubs & 9.8 & 12.2 & 5.4 & 0.74 \\
$\begin{array}{l}\text { Grasses } \\
\text { Rain-fed agriculture }\end{array}$ & 19.0 & 22.7 & 2.6 & 0.72 \\
$\begin{array}{l}\text { and pasture } \\
\text { Irrigated agriculture }\end{array}$ & 28.1 & 15.9 & 0.9 & 0.69 \\
and pasture & 0.1 & $<0.0$ & & 0.69 \\
\hline
\end{tabular}

grasses. Irrigated agriculture and pasture had the smallest percentage of correlated areas (Table 2) compared to other land cover classes.

The ecologically valuable floodplains and wetlands of the MDB made up $10.9 \%$ of the basin area and were of mixed land cover composition. The percentage of all areas with significant correlations between monthly SOI and phenological cycle peak magnitude in floodplains and wetlands was disproportionately higher $(14.8 \%)$ than the percentage of the area occupied by this zone $(10.9 \%)$. In addition, $6.1 \%$ of the floodplain and wetlands area showed significant relationships with monthly SOI, which is higher than for any of the individual land cover classes in Table 2. 


\section{Discussion}

\subsection{A phenological characterization of Australia that accommodates non-annual phenological cycles}

Our research characterized the cycles and variability of nonannual vegetation phenology across Australia, and identified their relationships with variability in rainfall and ENSOrelated large-scale atmospheric circulation. We provide a characterization of annual and non-annual phenological cycles of vegetation greening and browning for Australia based on MODIS EVI data.

We used an enhanced phenology model to characterize rainfall-driven phenology across the Australian continent, which includes large dryland regions. Very few studies have previously quantified the land surface phenology of dryland systems (Walker et al., 2014), likely due to the fact that the phenology of these systems is more complex than that of most temperature-limited regions (Walker et al., 2014; Primack and Miller-Rushing, 2011). Dryland phenology responds to a variable rainfall regime where the timing and magnitude of precipitation events varies inter-annually (Loik et al., 2004; Brown et al., 1997).

We identified and characterized rainfall-driven phenological cycles at any time of the year over a 14-year time series rather than within a predefined interval of every calendar year. This is important, as the timing of phenological cycles varied, and not every phenological cycle metric occurred in every year. We first identified points demarcating phenological cycles from the entire EVI time series, and then characterized the cycles using mathematical curves. For example, we did not identify a cycle peak for every year and every pixel (areas shown in gray in Fig. 6). However, this does not imply that no cycle occurred, but that the vegetation at these sites and points in time could be greening up towards a peak in the following year, browning down towards an end-of-cycle point, or in a phase between cycles. For example, the absence of peaks over interior Australia in 2005 and 2008 (Fig. 6) is also reflected in Fig. 2, where the vegetation at the Alice Springs site in interior Australia was in between phenological cycles. Phenological cycles thus need to be analyzed in the temporal context of multiple years. While most studies of phenology attempted to fit phenological curves within a predefined interval every calendar year, certain authors have proposed methods that include iterating the curve fitted to the vegetation index time series or by fitting a curve of vegetation index versus accumulated moisture (Tan et al., 2011; Brown and de Beurs, 2008). Our approach to characterize non-annual phenology can be applied to other areas with rainfall-driven phenology, and thus contributes to our understanding of non-annual, rainfall-driven phenological dynamics globally. While the results presented in this work focus on the phenological metrics of the first cycles of each year, a second cycle was not detected over most of Australia. For example, two peaks during a calendar year oc- curred over only $25 \%$ of the Australian land surface. Within the 14 years of the study, two peaks per year occurred no more than three times across $96 \%$ of Australia. Areas with two peaks per year occurred mostly in cropping or pasture land use (Fig. 10). An alternative method for identifying the number of cycles for broad regions can be found in Guan et al. (2014b).

\subsection{Phenology of Australia's interior}

For the interior of Australia, we identified a low phenological peak and minimum magnitude and the associated small amplitude (darker toned areas in both Fig. 4a and b), and high variability in magnitude, timing and the cycle integral. In addition, a peak was not identified in every year for large areas of the interior. Most areas of the interior are dryland systems with sparse vegetation cover and where vegetation phenology is driven by highly irregular rainfall timing and amounts (Australian Bureau of Meteorology, 2014c, e), and hydrologic regimes can be difficult to predict (Young and Kingsford, 2006). Thus, we do not see a strong phenological response (low amplitude); however, we interpret the high variability in the start of cycle and peak timing (Figs. 4 and 5) as a fast response to rainfall pulses, and the missing cycles (Fig. 5) were interpreted as dormant periods during dry years (Loik et al., 2004). We interpret these patterns of variable phenological cycles over interior Australia, where a cycle may vary in timing and length, or may skip a year entirely, to occur as a function of high climate variability. De Jong et al. (2012) identified frequent trend breaks of greening and browning over Australia that may be related to the non-annual phenological cycles identified here.

Desert river beds in the interior of the continent had a low minimum but moderate peak magnitude. The elevated peak magnitudes are caused by flooding driven by high amounts of distant rainfall (Young and Kingsford, 2006). The center of the arid Lake Eyre basin showed high variability in the minimum magnitude. Lake Eyre is the center of a sparsely vegetated, close drainage basin, and the fact that we identified high variability was in line with known flooding patterns, as this salt lake is reached by flooding only once in a century (McMahon et al., 2005). We interpret the positive anomaly in 2010 (Fig. 7) as a function of the La Niña floods (Australian Bureau of Meteorology, 2014a).

Conversely, large variability of peak timing and cycleintegrated greenness from one to another phenological cycle was found not just in the interior of Australia, but across most of the continent (Fig. 6 and Fig. 7). High inter-annual variability in water availability across most of Australia rather than for the continent's interior has also been demonstrated by the Australian Water Availability Project (2014). 


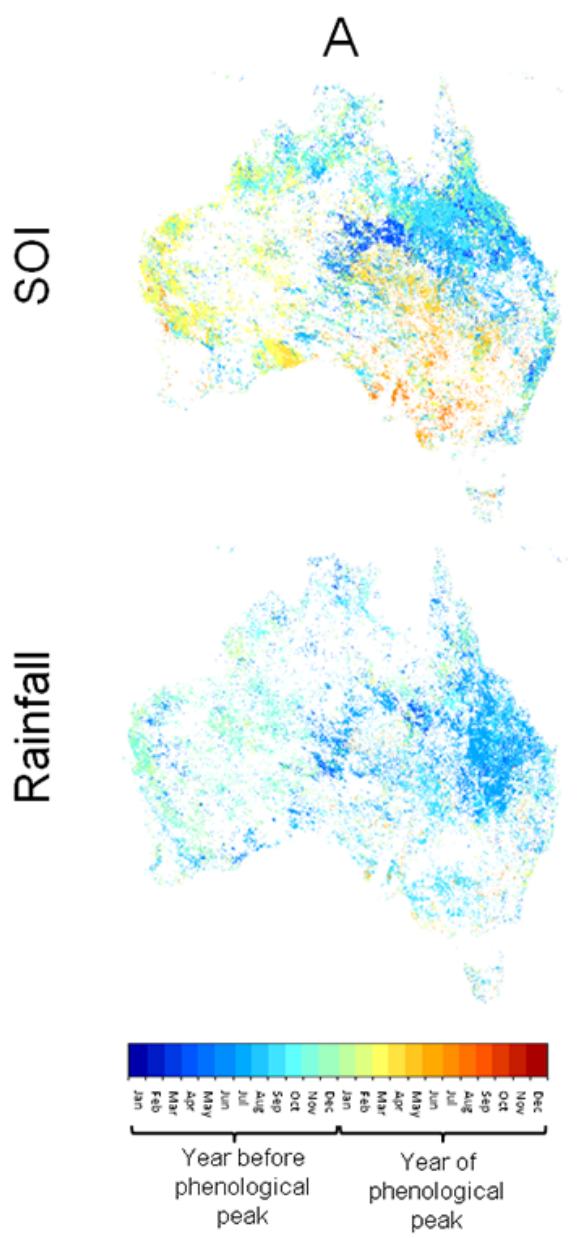

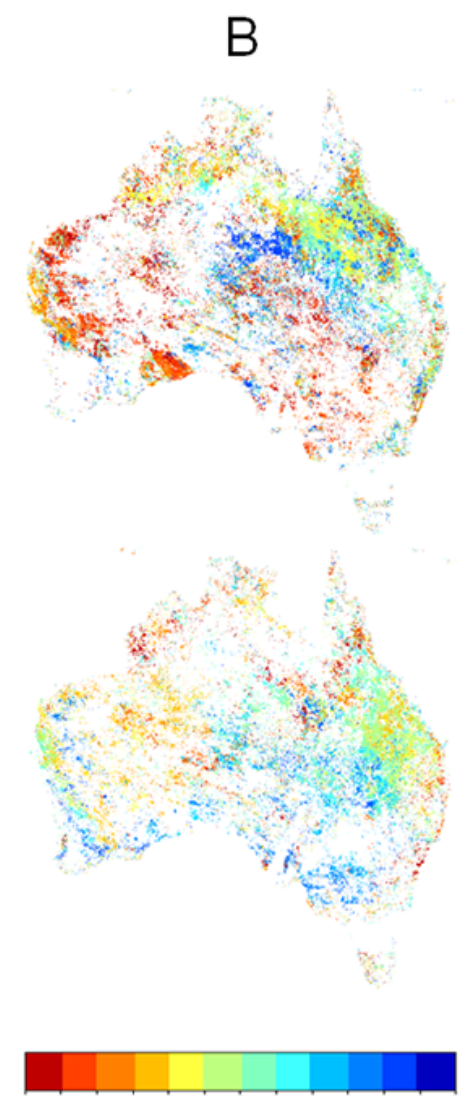

$\begin{array}{lllllllllllll}1 & 2 & 3 & 4 & 5 & 6 & 7 & 8 & 9 & 10 & 11 & 12\end{array}$

Number of month

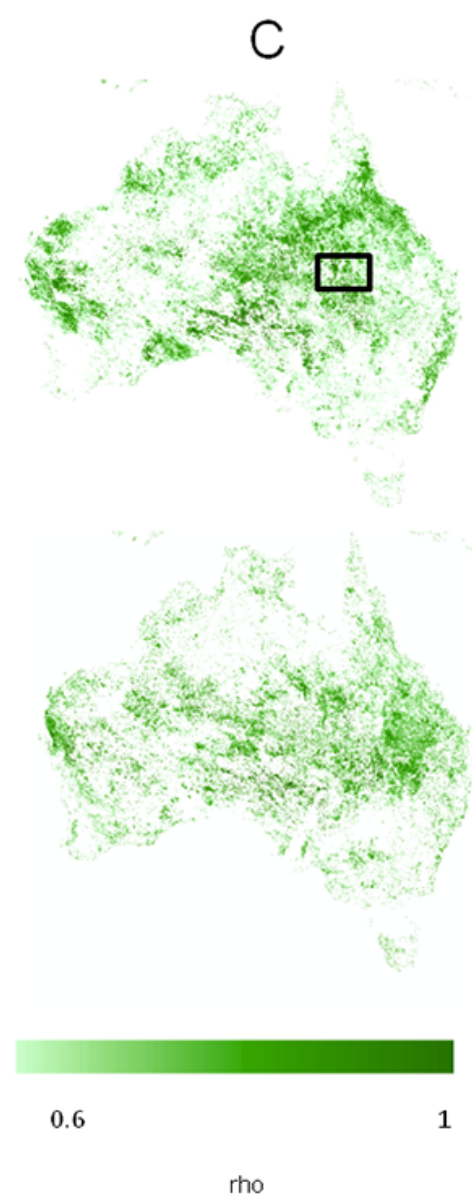

rho

Figure 8. Statistically significant relationships between monthly SOI and phenological cycle peak magnitude (top row) and monthly rainfall and phenological cycle peak magnitude (bottom row). (a) SOI and rainfall month most significantly correlated with peak magnitude. (b) Lead time of SOI and rainfall month relative to phenological peak and (c) Spearman's rho. Areas with $p>0.05$ shown in white. The black box in the top-right panel marks the extent of the area shown in Fig. 9, centered on the Cooper Creek floodplain in interior eastern Australia.

\subsection{Australia's phenology, the 2001-2009 Millennium Drought and a La Niña high precipitation event in 2010}

The years with widespread negative standard anomalies of cycle-integrated greenness coincided with the Millennium Drought from 2001 to 2009 (Heberger, 2011; Fig. 7). Dryland vegetation is subject to environmentally marginal conditions, and is therefore highly sensitive to climate variability (Hufkens et al., 2012; Brown et al., 1997).

However, the spatial extent of negative anomalies in certain years that extend beyond the dry interior suggested temporary yet severe drought-related water limitations also in the monsoonal north and the temperate areas of southeastern and southwestern Australia (Fig. 7). The large positive standardized anomalies of cycle-integrated greenness identified in this work across most of eastern Australia in 2010 (1-2 standard anomalies; Fig. 7) coincided with a strong La Niña event and associated high rainfall and floods that broke the Millennium Drought (Australian Bureau of Meteorology, 2014a; Heberger, 2011). This pattern includes the desert rivers extending from northeastern Australia to Lake Eyre, which experienced a major flood in 2010.

While the relationship between ENSO cycles and rainfall variability primarily over eastern Australia has been investigated before (van Dijk et al., 2013; Risbey et al., 2009), our research has quantified vegetation responses across Australia to the transition from a strong El Niño drought to La Niña wet periods. While the positive vegetation response to the 2010 La Niña occurred over eastern Australia, which is also influenced by ENSO cycles (van Dijk et al., 2013; Nicholls, 1991; Nicholls et al., 1997), the negative vegetation responses during the Millennium Drought cover a larger area, and occurred across the continent. 


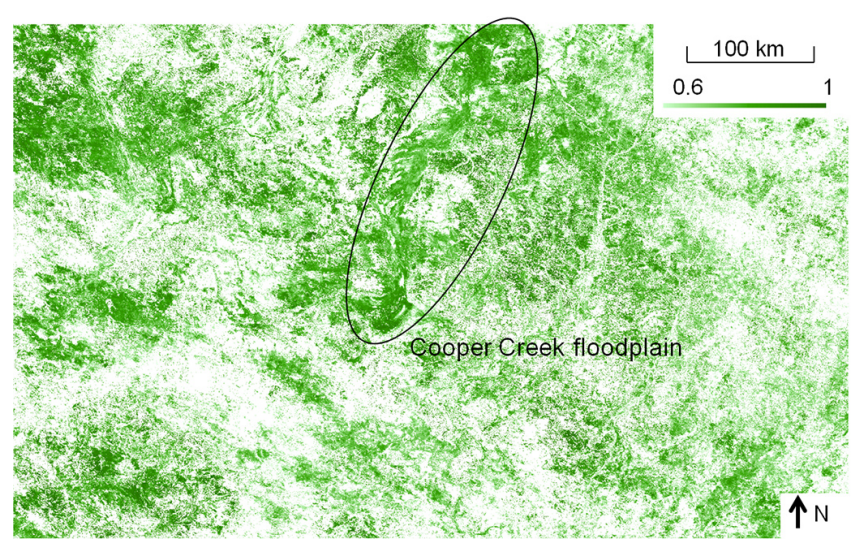

Figure 9. Significant Spearman rho correlations (shown in green) between monthly SOI and phenological cycle peak magnitude over a region in central Australia. The Cooper Creek floodplain of the middle reach of the Cooper Creek is visible in the center. Only areas with $p<0.05$ and rho $>=0.6$ are shown.

\subsection{Spatially explicit relationship between phenology and climatic variability}

We found that SOI-driven patterns of correlation with phenology covered a larger area compared to rainfall-driven patterns, likely because SOI is a more generic proxy of climatic variability that influences temperature, incoming solar radiation and rainfall rather than rainfall alone (Risbey et al., 2009; Australian Bureau of Meteorology, 2014f), and because ecosystems of Australia are limited not only by water availability, but also by temperature and radiation (Nemani et al., 2003).

The spatial extent of areas where we detected a correlation between SOI or rainfall and phenological metrics shrank with longer binning intervals of the climatic drivers. This suggested that relationships between climatic drivers and phenological variability were strongest for driver variability within a specific month of the year (e.g., SOI in September), as opposed to driver variability within for example a 6-month period (e.g., mean SOI across 6 months starting in April). This falls in line with the findings by Stone et al. (1996), who identified relationships between short-term SOI dynamics at specific times of the year and rainfall. Previous studies (e.g., Brown et al., 2010) using seasonal or longer temporal aggregation of driver variables may therefore not have identified the full spatial extent of correlation patterns.

We found the most concentrated significant correlation patterns between SOI and peak magnitude in northeastern Australia, which is in the proximity of the western Pacific convection variability indicated by SOI. We observed a similar yet less concentrated pattern for the rainfall-peak magnitude correlation. We interpret this latter pattern as primarily the effect of the large-scale atmospheric circulation patterns indicated by SOI. The lag times of correlations over northeastern Australia varied between 1 and 6 months fol-

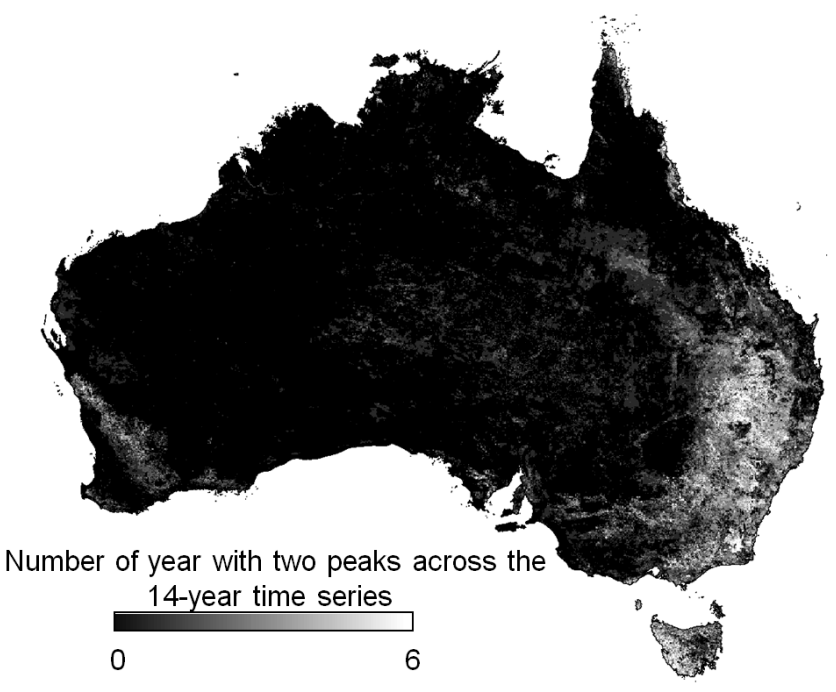

Figure 10. Number of years within the 14-year time series where two peaks were detected, mostly associated with cropping or pasture land (Fig. 1).

lowing SOI or rainfall. Shorter lag time (1-3 months) correlation patterns with SOI were observed near the western coast of Australia, yet lag times following rainfall were longer (5-8 months). These patterns are spatially remote from the variability in convection over the western Pacific (northeast of Australia) indicated by SOI. They may be related to the influence of the Indian Ocean Dipole (IOD) and the interaction between SOI and IOD (Risbey et al., 2009), which may explain the difference in lead time of the SOI and rainfall drivers. Over northeastern Australia and the eastern Australian interior, the identified 3-6 and 7-12 months' lag times of phenological cycle peak magnitude were similar for the SOI and the rainfall driver. The lag times identified here fell within the range of aggregation found by Andela et al. (2013), who related NDVI to rainfall. A study by Chen et al. (2014b) identified short lags (predominantly 1 month) between soil moisture and NDVI, which are shorter than most of the lags we identified here. Soil moisture in the previous month may provide the most direct relationship with vegetation response (as it represents water available to vegetation), but the climatic conditions that drive soil moisture may precede the soil moisture by a few months (Philippon et al., 2014). The identified increase in lag time between SOI and phenological peak magnitude and rainfall and phenological peak magnitude along a gradient of decreasing rainfall was in agreement with the findings by Andela et al. (2013). However, these findings contradict the concept that rainfall pulses drive rapid phenological responses (Loik et al., 2004). We interpret our findings as the dominating space-time relationship between large-scale atmospheric circulation pattern variability and phenological response. However, these patterns are unlikely to represent responses to individual storm events, and less significant relationships with 
a different SOI and rainfall month and lag time were also present, suggesting that vegetation responds to climatic variability on multiple timescales. A more in-depth analysis of the relationship between climatic drivers and phenological responses across multiple temporal scales should be investigated in future research.

The proportion of areas for which we identified significant correlations was generally smaller than those identified in other studies (e.g., Andela et al., 2013 and Chen et al., 2014a). This could be related to the relatively short time series we used and consequently the smaller power of our correlation analysis. Nonetheless, the spatial pattern of correlation was most widespread in northeastern Australia and along desert river beds (e.g., Cooper Creek) in the interior. These patterns agreed spatially with what would be expected from the SOI-approximated moisture source over the western Pacific and the associated progression of rainfall and runoff into interior Australia.

We conducted a higher spatial resolution correlation analysis for the MDB to investigate the sensitivity of the area's vegetation to SOI variability. The MDB contains the primary agricultural area of Australia, and the basin's agriculture was severely impacted by the Millennium Drought (van Dijk et al., 2013; Kirby et al., 2012; Heberger, 2011). We identified correlation patterns between SOI and peak magnitude primarily over natural vegetation cover, as opposed to areas used for dryland agriculture or pasture. As expected, irrigated agriculture had the lowest percentage of area, with significant correlations between SOI and phenological peak magnitude. The lowest percentage of areas with significant correlations over managed land may be explained by the effort that land managers and irrigators make to archive maximum production regardless of climatic variability (e.g., fertilization, use of pesticides, crop rotation, livestock density, movement and irrigation), whereas landscapes with natural vegetation cover may respond directly to climatic variability. In the context of climatic influence on agriculture in the MDB, van Dijk et al. (2013) suggested that the Millennium Drought impact on dryland wheat yields was offset by steady increases in cropped area and plant water use efficiency as well as possibly $\mathrm{CO}_{2}$ fertilization. As a zone of special interest within the MDB, we focused on floodplains and wetlands. These ecosystems were strongly impacted by the Millennium Drought and the 2010 La Niña floods (Australian Bureau of Meteorology, 2014b; Leblanc et al., 2012). Across the MDB's floodplains and wetlands, we identified the highest percentage of areas $(6.1 \%)$ with a significant correlation between SOI and phenological peak magnitude compared to other natural or managed land cover, highlighting the sensitivity of these ecosystems to ENSO-related climatic variability. We attributed the low percentage to limited test power as a function of the relatively short time series (14 years) used here. For example, Brown et al. (2010) found between 10 and $27 \%$ of certain areas in Africa to be significantly corre- lated with atmospheric indices using a 25-year AVHRR time series.

\subsection{Limitations and future work}

Several caveats to our work should be noted. When interpreting the phenological cycles characterized here, it should be noted that the sub-pixel composition of vegetation and background as well as multi-layer vegetation structure is unknown and may change over time (Zhang et al., 2009; Walker et al., 2012, 2014). Various methods for validating remotely sensed metrics of phenological cycles with ground-based observations have been discussed, including flux tower productivity time series, ground-based radiation sensor time series, phenocam time series as well as crowd-sourced citizen science (Richardson et al., 2007; Liang and Schwartz, 2009; Restrepo-Coupe et al., 2013). Validation of the phenological metrics developed here is currently underway.

The phenological metrics derived and described here represent different stages of vegetation growth. They have been made freely available in contribution to the Australian Terrestrial Ecosystem Research Network (TERN), and can be downloaded from the AusCover TERN Sydney node ${ }^{1}$ (http: //data.c3.uts.edu.au), providing opportunities for a range of applications.

In this work, we traced phenological cycles over time, quantified cycles' inter-annual variability, and investigated their relationship with rainfall and ENSO, thereby advancing phenological research for Australia, a country with extensive drylands. The phenological metrics provided here can be further used for characterizing the effect of anthropogenic disturbances on phenology and unraveling this effect from the influence of climatic forcing related to ENSO. Other opportunities for future work are the reanalysis of trends and trend breaks in vegetation phenological magnitude dynamics and climatic drivers (Donohue et al., 2009; de Jong et al., 2012; Chen et al., 2014a) and the relationship between vegetation phenological timing and climate control (Guan et al., 2014a).

\section{Conclusions}

We characterized vegetation phenological cycles that we derived from time series of Earth-observing satellite images from 2000 to 2013, across Australia, the driest inhabited continent. The precipitation-driven, non-annual phenology of Australia's drylands has not been previously studied in detail, and the relationship between phenology and climatic drivers including rainfall and SOI has not been previously quantified.

\footnotetext{
${ }^{1}$ The Australian Phenology Product is scheduled to migrate permanently to the Australian Research Data Storage Infrastructure $(R D S I)$ that is funded through the Australian Government's Super Science Initiative and sourced from the Education Investment Fund (EIF).
} 
We found the phenology of Australia's drylands to be highly variable across the time series, with shifts in phenological cycle peak timing of more than 1 month in the interior of the continent. Cycle-integrated greenness, a surrogate of vegetation productivity, shifted from negative to positive anomalies over most of eastern Australia with the transition from the El Niño-induced decadal droughts to flooding caused by La Niña. We related phenological magnitude response variability to the variability in rainfall and SOI across the continent and at a higher spatial resolution for the MDB, the main agricultural basin of Australia. We found the most widespread correlation patterns with single-month as opposed to multi-month aggregated drivers, suggesting that rainfall and SOI at a specific point in time is of primary importance in driving phenology. Correlation patterns between phenological magnitude response with rainfall and SOI occurred primarily over northeastern Australia and within the MDB, predominantly over natural land cover and particularly in floodplain and wetland areas, highlighting the sensitivity of these ecosystems to ENSO-related climatic variability.

A more in-depth analysis of the relationship between climatic drivers and phenological magnitude response across multiple temporal scales and including temperature and radiation drivers and driver combinations should be investigated in future research. Furthermore, the analysis of the relationship between phenological timing and climatic drivers should also be investigated.

Our approach could be valuable for other areas of rainfalldriven systems, and thus contributes to our understanding of non-annual phenological dynamics globally. The quantified spatial-temporal variability in phenology across Australia in response to climate variability presented here advances research of dryland phenology and provides important information for land management and climate change studies. The phenological metrics derived represent different stages of vegetation growth. They have been made freely available in contribution to the Australian Terrestrial Ecosystem Research Network (TERN), and can be downloaded from the AusCover TERN Sydney node, providing opportunities for a range of applications. The phenological metrics can be further used for characterizing the effect of anthropogenic disturbances on phenology and unraveling this effect from the influence of climatic forcing components and large-scale atmospheric circulation indices.

Acknowledgements. This research was supported by an Australian Research Council Discovery grant (DP1115479) entitled "Integrating remote sensing, landscape flux measurements, and phenology to understand the impacts of climate change on Australian landscapes" (A. Huete, CI), and by funding from the AusCover facility of the Australian Terrestrial Ecosystem Research Network (TERN). Calculations were performed at the University of Technology, Sydney eResearch high-performance computing facility.
M. G. Tulbure was partially funded through an Australian Research Council Discovery Early Career Researcher Award (DE140101608).

Edited by: K. Guan

\section{References}

Andela, N., Liu, Y. Y., van Dijk, a. I. J. M., de Jeu, R. a. M., and McVicar, T. R.: Global changes in dryland vegetation dynamics (1988-2008) assessed by satellite remote sensing: comparing a new passive microwave vegetation density record with reflective greenness data, Biogeosciences, 10, 6657-6676, doi:10.5194/bg10-6657-2013, 2013.

Australian Bureau of Meteorology: The 2010-2011 La Niña: Australia soaked by one of the strongest events on record, available at: http://www.bom.gov.au/climate/enso/feature/ENSO-feature. shtml, 2014a.

Australian Bureau of Meteorology: El Niño - Detailed Australian Analysis and La Niña - Detailed Australian Analysis, available at: http://www.bom.gov.au/climate/enso/enlist/; http://www. bom.gov.au/climate/enso/lnlist/, 2014b.

Australian Bureau of Meteorology: Climate Data Online: Average annual, seasonal and monthly rainfall $(\mathrm{mm})$ and Rainfall variability (index of variability), available at: www.bom.gov.au/climate/ data/index.shtml, 2014c.

Australian Bureau of Meteorology: Southern Oscillation Index Data, available at: http://www.bom.gov.au/climate/current/soi2. shtml, 2014d.

Australian Bureau of Meteorology: Rainfall variability, available at: http://www.bom.gov.au/jsp/ncc/climate_averages/ rainfall-variability/index.jsp, 2014e.

Australian Bureau of Meteorology: ENSO impacts - temperature, available at: http://www.bom.gov.au/climate/enso/history/ ln-2010-12/ENSO-temperature.shtml, 2014f.

Bradley, B. A. and Mustard, J. F.: Comparison of phenology trends by land cover class: a case study in the Great Basin, USA, Glob. Change Biol., 14, 334-346, 2007.

Brown, J. H., Valone, T. J., and Curtin, C. G.: Reorganization of an arid ecosystem in response to recent climate?change, Proc. Natl. Ac. Sci., 94, 9729-9733, 1997.

Brown, M. E. and de Beurs, K. M.: Evaluation of multi-sensor semiarid crop season parameters based on NDVI and rainfall, Remote Sens. Environ., 112, 2261-2271, 2008.

Brown, M. E., de Beurs, K., and Vrieling, A.: The response of African land surface phenology to large scale climate oscillations, Remote Sens. Environ., 114, 2286-2296, 2010.

Chen, B., Xu, G., Coops, N. C., Ciais, P., Innes, J. L., Wang, G., Myneni, R. B., Wang, T., Krzyzanowski, J., Li, Q., Cao, L., and Liu, Y.: Changes in vegetation photosynthetic activity trends across the Asia-Pacific region over the last three decades, Remote Sens. Environ., 144, 28-=41, 2014a.

Chen, T., de Jeu, R. a. M., Liu, Y. Y., van der Werf, G. R., and Dolman, a. J.: Using satellite based soil moisture to quantify the water driven variability in NDVI: A case study over mainland Australia, Remote Sens. Environ., 140, 330-338, 2014b.

Connell, D.: Water politics in the Murray-Darling basin, Federation Press, 2007. 
de Beurs, K. M., and Henebry, G. M.: Spatio-temporal statistical methods for modeling land surface phenology, in: Phenological Research, edited by: Hudson, I. L. and Keatley, M. R., Springer, Dordrecht, 2008.

de Jong, R., Verbesselt, J., Schaepman, M. E., and Bruin, S.: Trend changes in global greening and browning: contribution of shortterm trends to longer-term change, Glob. Change Biol., 18, 642$655,2012$.

Delbart, N., Kergoat, L., Le Toan, T., Lhermitte, J., and Picard, G.: Determination of phenological dates in boreal regions using normalized difference water index, Remote Sens. Environ., 97, 2638, 2005.

Donohue, R. J., McVicar, T. R., and Roderick, M. L.: Climaterelated trends in Australian vegetation cover as inferred from satellite observations, 1981-2006, Glob. Change Biol., 15, 10251039, 2009.

Dougherty, R. L., Edelman, A., and Hyman, J. M.: Nonnegativity-, Monotonicity-, or Convexity-Preserving Cubic and Quintic Hermite Interpolation, Mathem. Computat., 52, 471-794, 1989.

Eklundh, L. and Jönsson, P.: TIMESAT 3.0 Software Manual, 1-74. (http://www.nateko.lu.se/timesat/docs/timesat3_1_1_ SoftwareManual.pdf), 2010.

Friedl, M., Henebry, G., Reed, B., Huete, A., White, M., Morisette, J., Nemani, R., Zhang, X., and Myneni, R.: Land surface phenology, A Community White Paper requested by NASA, 10 April 2006.

Ganguly, S., Friedl, M. A., Tan, B., Zhang, X., and Verma, M.: Remote Sensing of Environment Land surface phenology from MODIS : Characterization of the Collection 5 global land cover dynamics product, Remote Sens. Environ., 114, 1805-1816, 2010.

Goddard Space Flight Center: Tropical Rainfall Monitoring Mission Project TRMM_3B43.v7 product, USGS/Earth Resources Observation and Science (EROS) Center, Sioux Falls, South Dakota, http://trmm.gsfc.nasa.gov/, 2014.

Guan, K., Medvigy, D., Wood, E. F., Caylor, K. K., Li, S., and Jeong S. J.: Deriving vegetation phenological time and trajectory information over Africa using SEVIRI daily LAI, IEEE Ttrans. Geosci. Remote Sens., 53, 1113-1130, 2014a.

Guan, K., Wood, E. F., Caylor, K. K., Medvigy, D., Sheffield, J., Pan, M., Kimball, J., Xu, X., and Jones, M. O.: Terrestrial hydrological control on vegetation phenology of African savannas and woodlands, J. Geophys. Res. Biogeosciences, accepted, 2014b.

Heberger, M.: Australia's Millennium Drought: Impacts and Responses, in: The World's Water, edited by: Gleick, P. H., Island Press/Center for Resource Economics, 97-125, 2011.

Huete, A., Didan, K., Miura, T., Rodriguez, E. P., Gao, X., and Ferreira, L. G.: Overview of the radiometric and biophysical performance of the MODIS vegetation indices, Remote Sens. Environ., 83, 195-213, 2002.

Huete, A., Miura, T., Yoshioka, H., Ratana, P., and Broich, M.: Indices of Vegetation Activity, in, edited by: Hanes, J., Springer, Berlin Heidelberg, 2014.

Hufkens, K., Friedl, M., Sonnentag, O., Braswell, B. H., Milliman, T., and Richardson, A. D.: Linking near-surface and satellite remote sensing measurements of deciduous broadleaf forest phenology, Remote Sens. Environ., 117, 307-321, 2012.

IPCC: Climate Change 2001: impacts, adaptation, and vulnerability, Contribution of working group II to the third assessment re- port of the Intergovernmental Panel on Climate Change (IPCC), Cambridge University Press, Cambridge, 2001.

IPCC: Climate change 2007 - impacts, adaptation and vulnerability, Contribution of Working Group II to the Fourth Assessment Report of the IPCC, Cambridge University Press, Cambridge, 2007.

IPCC: Climate Change 2013: The Physical Science Basis, Contribution of Working Group I to the Fifth Assessment Report of the Intergovernmental Panel on Climate Change, Cambridge University Press, Cambridge, 2013.

Jones, M. O., Jones, L. a., Kimball, J. S., and McDonald, K. C.: Satellite passive microwave remote sensing for monitoring global land surface phenology, Remote Sens. Environ., 115, 1102-1114, 2011.

Keatley, M. R., Chambers, L. E., and Phillips, R.: Australia and New Zealand, in: Phenology: an Integrative Environmental Science, edited by: Schwartz, M. D., Springer, Dordrecht, 23-52, 2013.

Kingsford, R. T., Brandis, K., Thomas, R. F., Crighton, P., Knowles, E., and Gale, E.: Classifying landform at broad spatial scales: the distribution and conservation of wetlands in New South Wales, Australia, Mar. Fresh. Res., 55, 17-31, 2004.

Kirby, M., Connor, J., Bark, R., Qureshi, E., and Keyworth, S.: The economic impact of water reductions during the Millennium Drought in the Murray-Darling Basin, AARES conference, 2012, 7-10, 2012.

Köppen, W.: The thermal zones of the Earth according to the duration of hot, moderate and cold periods and of the impact of heat on the organic world. (translated and edited by Volken, E. and S. Brönnimann), Meteorologische Zeitschrift, 1, 351-360, 1884.

Leblanc, M., Tweed, S., Van Dijk, A., and Timbal, B.: A review of historic and future hydrological changes in the Murray-Darling Basin, Glob. Planet. Change, 80/81, 226-246, 2012.

Lehmann, E. L. and D'Abrera, H. J. M.: Nonparametrics: statistical methods based on ranks, Holden-Day, 1975.

Liang, L. and Schwartz, M.: Landscape phenology: an integrative approach to seasonal vegetation dynamics, Lands. Ecol., 24, 465-472, 2009.

Loik, M., Breshears, D., Lauenroth, W., and Belnap, J.: A multiscale perspective of water pulses in dryland ecosystems: climatology and ecohydrology of the western USA, Oecologia, 141, 269-281, 2004.

Lymburner, L., Tan, P., Mueller, N., Thackway, R., Lewis, A., Thankappan, M., Randall, L., Islam, A., and Senarath, U.: The National Dynamic Land Cover Dataset, Geoscience Australia, Symonston, Australia, p. 105, 2011.

Ma, X., Huete, A., Yu, Q., Coupe, N. R., Davies, K., Broich, M., Ratana, P., Beringer, J., Hutley, L. B., Cleverly, J., Boulain, N., and Eamus, D.: Spatial patterns and temporal dynamics in savanna vegetation phenology across the North Australian Tropical Transect, Remote Sens. Environ., 139, 97-115, 2013.

McMahon, T. A. T. A., Murphy, R., Little, P., Costelloe, J. F., Peel, M. C. M. C., Chiew, F. H. S., Hayes, S., Nathan, R. J. R. J., Kandel, D. D., (Firm), S. K. M., Engineering, U. o. M. D. o. C. a. E., and Heritage, A. D. o. t. E. a.: Hydrology of Lake Eyre Basin, edited by: McMahon, T. A., Murphy, R., Little, P., Costelloe, J. F., Peel, M. C., Chiew, F. H. S., Hayes, S., Nathan, R., Kandel, D. D., Canberra, Australian Capital Territory, Natural Heritage Trust, 2005. 
Moulin, S., Kergoat, L., Viovy, N., and Dedieu, G.: Global-Scale Assessment of Vegetation Phenology Using NOAA/AVHRR Satellite Measurements, J. Climate, 10, 1154-1170, 1997.

Myneni, R. B., Keeling, C. D., Tucker, C. J., Asrar, G., and Nemani, R. R.: Increased plant growth in the northern high latitudes from 1981 to 1991, Nature, 386, 698-702, 1997.

Nemani, R. R., Keeling, C. D., Hashimoto, H., Jolly, W. M., Piper, S. C., Tucker, C. J., Myneni, R. B., and Running, S. W.: ClimateDriven Increases in Global Terrestrial Net Primary Production from 1982 to 1999, Science, 300, 1560-1563, 2003.

Nicholls, N.: The El Niño/Southern Oscillation and Australian vegetation, Vegetatio, 91, 23-36, 1991.

Nicholls, N., Drosdowsky, W., and Lavery, B.: Australian rainfall variability and change, Weather, 52, 66-72, 1997.

OzFlux: Australian and New Zealand Flux Research and Monitoring, http://www.ozflux.org.au/, 2014.

Peñuelas, J., Rutishauser, T., and Filella, I.: Phenology Feedbacks on Climate Change, Science, 324, 887-888, 2009.

Philippon, N., Martiny, N., Camberlin, P., Hoffman, M. T., and Gond, V.: Timing and patterns of ENSO signal in Africa over the last 30 years: insights from Normalized Difference Vegetation Index data, J. Climate, 27, 2509-2532, 2014.

Pitman, A. J.: The evolution of and revolution in, land surface schemes designed for climate models, Int. J. Climatol., 23, 479510, 2003.

Ponce Campos, G. E., Moran, M. S., Huete, A., Zhang, Y., Bresloff, C., Huxman, T. E., Eamus, D., Bosch, D. D., Buda, A. R., Gunter, S. A., Scalley, T. H., Kitchen, S. G., McClaran, M. P., McNab, W. H., Montoya, D. S., Morgan, J. A., Peters, D. P. C., Sadler, E. J., Seyfried, M. S., and Starks, P. J.: Ecosystem resilience despite large-scale altered hydroclimatic conditions, Nature, 494, 349352, 2013.

Primack, R. B. and Miller-Rushing, A. J.: Broadening the study of phenology and climate change, New Phytologist, 191, 307-309, 2011.

Restrepo-Coupe, N., Huete, A., Broich, M., and Davies, K.: Phenology Validation, in: Terrestrial Ecosystem Research Network, 2013.

Richardson, A., Jenkins, J., Braswell, B., Hollinger, D., Ollinger, S., and Smith, M.-L.: Use of digital webcam images to track spring green-up in a deciduous broadleaf forest, Oecologia, 152, 323334, 2007.

Richardson, A. D., Keenan, T. F., Migliavacca, M., Ryu, Y., Sonnentag, O., and Toomey, M.: Climate change, phenology, and phenological control of vegetation feedbacks to the climate system, Agr. Forest Meteorol., 169, 156-173, 2013.

Risbey, J. S., Pook, M. J., McIntosh, P. C., Wheeler, M. C., and Hendon, H. H.: On the Remote Drivers of Rainfall Variability in Australia, Month. Weather Rev., 137, 3233-3253, 2009.

Savitzky, A. and Golay, M. J. E.: Smoothing and Differentiation of Data by Simplified Least Squares Procedures, Analyt. Chem., 36, 1627-1639, 1964.

Schwartz, M.: Introduction, in, edited by: Schwartz, M., Tasks for Vegetation Science, Springer, Netherlands, 3-7, 2003.
Schwartz, M. D.: Preface, in: Phenology: An Integrative Environmental Science, edited by: Schwartz, M. D., Springer, Dordrecht, 2013.

Stone, R. C., Hammer, G. L., and Marcussen, T.: Prediction of global rainfall probabilities using phases of the Southern Oscillation Index, Nature, 384, 252-255, 1996.

Tan, B., Morisette, J. T., Wolfe, R. E., Gao, F., Ederer, G. A., Nightingale, J., and Pedelty, J. A.: An Enhanced TIMESAT Algorithm for Estimating Vegetation Phenology Metrics From MODIS Data, IEEE J. Select. Top. Appl. Earth Observat. Remote Sens., 4, 361-371, 2011.

Trenberth, K. E. and Caron, J. M.: The Southern Oscillation Revisited: Sea Level Pressures, Surface Temperatures, and Precipitation, J. Climate, 13, 4358-4365, 2000.

United Nations: Global Drylands: A UN system-wide response, Geneva, Switzerland, 2011.

van Dijk, A. I. J. M., Beck, H. E., Crosbie, R. S., de Jeu, R. a. M., Liu, Y. Y., Podger, G. M., Timbal, B., and Viney, N. R.: The Millennium Drought in southeast Australia (2001-2009): Natural and human causes and implications for water resources, ecosystems, economy, and society, Water Resour. Res., 49, 1040-1057, 2013.

Walker, J. J., de Beurs, K. M., Wynne, R. H., and Gao, F.: Evaluation of Landsat and MODIS data fusion products for analysis of dryland forest phenology, Remote Sens. Environ., 117, 381-393, 2012.

Walker, J. J., de Beurs, K. M., and Wynne, R. H.: Dryland vegetation phenology across an elevation gradient in Arizona, USA, investigated with fused MODIS and Landsat data, Remote Sens. Environ., 144, 85-97, 2014.

White, M. A., Thornton, P. E., and Running, S. W.: A continental phenology model for monitoring vegetation responses to interannual climatic variability, Global Biogeochem. Cy., 11, 217-234, 1997.

Young, W. J. and Kingsford, R. T.: Flow variability in large unregulated dryland rivers, in: Ecology of Desert Rivers, edited by: R. T., Kingsford, Cambridge University Press, Cambridge 2006.

Zhang, X., Friedl, M. A., and Schaaf, C. B.: Monitoring vegetation phenology using MODIS, Remote Sensing of Environment, 84, 471-475, 2003.

Zhang, X., Friedl, M. A., and Schaaf, C. B.: Sensitivity of vegetation phenology detection to the temporal resolution of satellite data, Int. J. Remote Sens., 30, 2061-2074, 2009.

Zhang, X. Y., Friedl, M. A., and Tan, B.: Long-term detection of global vegetation phenology from satellite instruments, in: InTech, edited by: Zhang, X., InTech, 2012.

Zhang, Y., Susan Moran, M., Nearing, M. A., Ponce Campos, G. E., Huete, A. R., Buda, A. R., Bosch, D. D., Gunter, S. A., Kitchen, S. G., Henry McNab, W., Morgan, J. A., McClaran, M. P., Montoya, D. S., Peters, D. P. C., and Starks, P. J.: Extreme precipitation patterns and reductions of terrestrial ecosystem production across biomes, J. Geophys. Res. Biogeosciences, 118, 148-157, 2013, http://www.biogeosciences.net/118/148/2013/. 